Katarzyna Wolff

Warszawa

\title{
Dawne i nowe dylematy badań czytelnictwa
}

Badania czytelnictwa mają w Polsce (podobnie jak w innych krajach) dość długą tradycję, uznany dorobek, a wiedza $z$ tego zakresu wykładana jest na niektórych kierunkach humanistycznych, m.in. na bibliotekoznawstwie, kulturoznawstwie, polonistyce. Czytelnictwo nie jest jednak samodzielną dyscypliną i w zależności od usytuowania, przyjmowanych założeń, rozstrzygnięć metodologicznych, formulowanych celów mamy do czynienia $\mathrm{z}$ różnymi realizacjami i różnego rodzaju dylematami, towarzyszącymi badaniom. Spróbujmy zatem przyjrzeć się niektórym $z$ nich, zarówno obserwowanym od dawna, jak i nowym, prezentując przykładowe konsekwencje konkretnych wyborów metodologicznych lub - tam, gdy ciągle jeszcze więcej niewiadomych niż stwierdzeń - przynajmniej zachęcić do dyskusji.

\section{Krótki przegląd badań czytelnictwa w Polsce}

Zainteresowanie stanem czytelnictwa w Polsce należy łączyć ze stopniowym poszerzaniem skladu społecznego zbiorowości czytającej, którego początki datuje się na przełom XIX i XX wieku' ${ }^{1}$ W tym czasie umiejętność czytania, oprócz inteligencji, szlachty, przedstawicieli środowisk urzędniczych i rzemieślniczo-kupieckich, zaczęła pojawiać się także wśród robotników i chłopów. W poświęconych tej kwestii rozpoznaniach (czy to zrealizowanych, czy jedynie postulowanych) uczestnictwo w kulturze druku traktowano jako najpełniejsza i najbardziej wartościową formę partycypacji w kulturze narodowej, a zarazem przejaw cywilizacyjnego awansu grup i warstw społecznych dotychczas w kulturze tej nieuczestniczących. Już wówczas też dość powszechnie posługiwano się samym terminem „czytelnictwo", raczej go jednak nie definiując, i nie wdając się $w$ teoretyczne rozważania. Natomiast zakres i charakter pytań, czy to kierowanych wprost do wybranych grup respondentów, czy pozwalających porządkować dane statystyczne wytwarzane przez odpowiednie instytucje (czy-

\footnotetext{
${ }^{1}$ Szczególowo początki badań czytelnictwa w Polsce omawia Anna Zdanowicz w artykulach opublikowanych w: Ludzie i ksiqzżi, red. J. Kostecki, Warszawa 2006 - Pierwsze polskie próby badań nad czytelnictwem (1881-1918), s. 149-180, oraz Badania nad czytelnictwem w okresie II Rzeczypospolitej, s. 181-202. Na ten temat zob. także: J. Andrzejewska, Badania czytelnictwa w Polsce do 1939 roku, ,Studia o Książce”, t. 16, Wroclaw 1986, i tejże, $Z$ dziejów badań nad czytelnictwem w Polsce (do roku 1939), „Roczniki Biblioteczne", 32:1988, z. 2 .
} 
telnie, wypożyczalnie, redakcje czasopism, wydawnictwa) wskazuje, że do zdgadnienia podchodzono dość szeroko. Dziś powiedzielibyśmy, że uwzględniano (lub jedynie proponowano uwzględniać): wybory i preferencje czytelników, ich kanony lekturowe, wartości konstytuujące się wokół i za sprawą lektury, biografie czytelnicze, umieszczając wskaźniki dotyczące czytania na stosunkowo szerokim spolecznym i kulturowym tle. Generalnie zawodzilo jednak rozpoznanie badanych środowisk, a co za tym idzie także odpowiedni dobór metod i narzędzi, dostosowanych do charakteru obserwowanych zbiorowości (przykładem ambitne próby badania czytelnictwa chłopów podjęte w ostatniej dekadzie XIX w. przez Antoniego Potockiego i Zygmunta Wasilewskiego oraz Mieczysława Brzezińskiego), a w niektórych pracach także (na przykład szeroko zakrojone badania wśród robotników przemyslu cukrowniczego w Królestwie Polskim autorstwa Konstantego B. Krzeczkowskiego) interpretacja wyników, $\mathrm{z}$ reguły podporządkowana określonym założeniom ideologicznym. Jak pisze Anna Zdanowicz: „Większość przedsięwzięć rodzila się z przekonania o silnym wpływie, ważności i skuteczności lektury; chciano się upewnić co do jej roli w kształtowaniu i zmianie świadomości"2.

W okresie II Rzeczypospolitej liczba badań na temat czytelnictwa znacznie wzrosła (co należy łączyć $z$ jednej strony $z$ poszerzaniem zbiorowości czytelników, $z$ drugiej zaś $-z$ umieszczaniem działan zwiąanych $z$ propagowaniem czytania w różnego rodzaju ruchach spolecznych i patronackich), powszechnie zaczął być stosowany także sam termin, pojawiły się próby ujęcia teoretycznego ${ }^{3}$. $\mathrm{W}$ podejmowanych badaniach dominowało jednakże podejście typowo pragmatyczne: rozpoznania służć miały doskonaleniu pracy oświatowo-kulturalnej prowadzonej w bibliotekach, czytelniach, świetlicach, wpływać na racjonalizację polityki wydawniczej, kształtowanie zbiorów bibliotek, czy nawet edukację m.in. poprzez odpowiedni, uwzględniający preferencje młodzieży, dobór lektur szkolnych. Ich autorzy to m.in. Helena Radlińska, Stanisław Orsini-Rosenberg, Paweł Rybicki, Aniela Mikucka, Maksymilian J. Ziomek. Postawę badawczą, jaką prezentowali w swoich pracach, cechował jednak znaczny stopień zideologizowania (zwłaszcza w badaniach dzieci i młodzieży oraz środowisk, do których adresowano gros działań oświatowych). Wysoką wartość książki traktowano jako swego rodzaju dogmat, który ponadto formulowano $z$ charakterystyczną dla tego okresu emfazą. Przykładem może być misja, jaką ksiażce wyznaczała Helena Radlińska: „Książka towarzyszy człowiekowi we wszystkich niemal dziedzinach życia; bywa informatorem i doradca, zapala, uczy, bawi. Jest najważniejszym narzędziem pracy umysłowej, bez której nie masz żadnej innej pracy. Nie tylko student, nauczyciel, referent, lecz również rzemieślnik, rolnik, miłośnik pracy ręcznej nie może obyć się bez pomocy książki. Książka potrzebna jest każdemu, kto chce się zorientować w swych prawach i obowiazkach, znaleźć sobie miejsce

\footnotetext{
${ }^{2}$ A. Zdanowicz, dz. cyt., s. 179.

${ }^{3}$ Por. A Mikucka, Przedmiot, zakres $i$ metody badań nad czytelnictwem, Warszawa 1938.
} 
na świecie”4 oraz w innym miejscu: „Książka jest powolana do przezwyciężania zła, które niesie bierne poddawanie się oddziaływaniu prasy, radia, kina"5.

Jednocześnie kwestie związane $z$ czytaniem książek i prasy w połączeniu z funkcjonowaniem instytucji oświatowych i kulturalnych weszły w obszar zainteresowań socjologów, pełniąc rołę materiału źródłowego dokumentującego przemiany świadomościowe, jakie na początku XX w. miały miejsce na polskiej wsi ${ }^{6}$. W pracach Floriana Znanieckiego i Williama I. Thomasa oraz Józefa Chałasińskiego zagadnienia należące do obszaru czytelnictwa nie stanowiły wprawdzie autonomicznego przedmiotu badań, lecz poddane rygorowi badawczemu socjologii (założenia teoretyczne, metodologia, narzędzia, analiza źródel) zyskały zupełnie nowy kontekst - nie jak wcześniej głównie praktyczny, lecz poznawczy: społeczny i kulturowy ${ }^{7}$. Z dzisiejszej perspektywy bardzo obiecująco przedstawia się także, niestety niezrealizowana, propozycja socjologicznych badań nad czytelnictwem Pawła Rybickiego ${ }^{8}$. Jego postulat, by badać „społeczne kręgi czytelnicze”, grupy, które wyznaczają „normy czytania”, a przede wszystkim brać pod uwagę uwarunkowania (narodowe, klasowe, towarzyskie) oddziałujące na ksztalt zachowań czytelniczych, brzmią bardzo współcześnie.

W tym czasie pojawiła się także potrzeba instytucjonalnego umocowania badań czytelnictwa - wymienić należy tu m.in. inicjatywę Polskiego Towarzystwa Wydawców Książek czy Sekcję Badań Czytelnictwa Koła Warszawskiego Związku Bibliotekarzy oraz - co prawda tylko na etapie projektu - pomysł, przygotowany przez Związek Bibliotekarzy Polskich i ogłoszony w 1938 r., utworzenia odrębnego instytutu, którego działalność miałaby się rozwijać w trzech kierunkach, w tym: „naukowo-badawczym w zakresie czytelnictwa i bibliologii”.

Powojenne próby kontynuowaniabadań,podejmowanem.in.przezPaństwowy Instytut Książki pod kierunkiem Adama Łysakowskiego oraz Biuro Badania Czytelnictwa Spółdzielni Wydawniczo-Oświatowej „Czytelnik”, zakończyły się szybko i dramatycznie w momencie, gdy rządząca ekipa uznała książkę za jedno z głównych narzędzi „rewolucji kulturalnej” ${ }^{10}$. Termin „czytelnictwo” zawłaszczyli partyjni ideologowie, posługując się nim nie w celu rozpoznania autentycznych potrzeb i zainteresowań odbiorców, lecz w poszukiwaniu takich środków oddziaływania, które miały doprowadzić do przebudowy człowieka, jak stwierdzal bowiem jeden z czolowych ówczesnych partyjnych działaczy „frontu ideologicz-

${ }^{4}$ Cyt. za A. Zdanowicz, dz. cyt., s. 201-202.

${ }^{5}$ H. Radlińska, Książa wśród ludzi, Warszawa 1949, s. 15.

${ }^{6}$ Wśród prekursorów takiego podejścia wymienić należy przede wszystkim Franciszka Bujaka jako autora pierwszych na gruncie polskim naukowych monografii wsi: Maszkiewic, Limanowej i Zmiącej.

${ }^{7}$ F. Znaniecki, W. I. Thomas, Chtop polski w Europie i Ameryce, Warszawa 1976; J. Chalasiński, Mtode pokolenie chtopów, t. 3 i 4, Warszawa 1938, oraz tenże, Drogi awansu spotecznego robotnika, Poznań 1931.

${ }^{8}$ P. Rybicki, Socjologia czytelnictwa, w: IV Zjazd Bibliotekarzy Polskich $w$ Warszawie. Referaty, cz. II. Warszawa 1936, oraz na ten temat A. Zdanowicz, dz. cyt.

${ }^{9}$ Cyt. za N. Kraśko, Instytut Ksiązki i Czytelnictwa - ksztattowanie się struktury i zakresu zainteresowań, w: Ludzie i ksiązki, s. 205.

${ }^{10}$ Zob. na ten temat S. A. Kondek, Papierowa rewolucja. Oficjalny obieg ksiqżek $w$ Polsce $w$ latach 1948-1955, Warszawa 1999 . 
nego” - „rewolucja kulturalna to w wysokiej mierze treści czytelnictwa"11. W rezultacie nieliczne doniesienia $z$ tego okresu na temat czytelnictwa $z$ nauką nie miały nic wspólnego, lecz były tekstami czysto propagandowymi ${ }^{12}$. Dodajmy, że w tym samym czasie doszło do usunięcia $z$ uniwersytetów socjologii jako „nauki burżuazyjnej" i całkowitej likwidacji badań spolecznych ${ }^{13}$. O powrocie do badań czytelnictwa można mówić w zasadzie dopiero po 1956 r., choć już wcześniej wobec dysfunkcjonalności rynku wydawniczo-księgarskiego, wynikającej z ogromnej nadprodukcji ksiązek nieznajdujących zbytu, wśród przedstawicieli władz partyjnych zaczęły pojawiać się głosy o konieczności analizowania rzeczywistych lekturowych potrzeb społeczeństwa i różne pomysły odnośnie ich praktycznej realizacji ${ }^{14}$. W rezultacie w 1954 r. na mocy uchwały Rady Ministrów przy Bibliotece Narodowej utworzony zostal Instytut Książi i Czytelnictwa (faktyczna dzialalność placówki datuje się od kwietnia 1955 r.), który na podstawie Statutu Biblioteki Narodowej: „prowadzi badania w zakresie bibliotekoznawstwa, metodyki i technik pracy bibliotekarskiej, racjonalizacji i postępu technicznego oraz czytelnictwa, ksiegarstwa, polityki wydawniczej, kształcenia bibliotekarzy, historii książki i bibliotek w XIX i XX w., zajmuje się upowszechnianiem wyników badawczych, a także prowadzi normalizacje bibliotekarską oraz poradnictwo w zakresie powyższej problematyki"15. Powiedzmy też od razu, że również obecnie obowiązujący statut nakłada na Bibliotekę Narodową obowiązek prowadzenia badań w dziedzinie czytelnictwa ${ }^{16}$. W praktyce spoczywa on nadal na Instytucie Książki i Czytelnictwa (IKiCz) i jego dwu pracowniach: Pracowni Badań Czytelnictwa, gdy chodzi o badania współczesne, i Pracowni Badania Historii Czytelnictwa, w odniesieniu do badań historycznych - nadal też gros prac badawczych z tego zakresu (zwłaszcza dotyczących wspólczesności), prowadzonych w Polsce, jest realizowanych w tej placówce ${ }^{17}$. Mają one głównie charakter materiałowy, lecz powstają w oparciu o przez lata wypracowywaną metodologię, której towarzyszy określona refleksja teoretyczna. W dalszej części niniejszego artykułu skupiać

${ }^{11}$ Tamże, s. 16.

${ }^{12}$ Zob. m.in. Cz. Koziol, $Z$ zagadnień upowszechniania czytelnictwa przez biblioteki, w: $Z$ zagadnień czytelnictwa w Polsce Ludowej, Warszawa 1952, M. Lisowska, Ankieta koszalińska, „Nowa Kultura”, 1953, nr 20.

${ }^{13}$ Zob. na ten temat N. Kraśko, Instytucjonalizacja socjologii w Polsce: 1920-1970, Warszawa 1996, s. 121-150.

${ }^{14}$ Szczególowo pisze o tym S. Kondek, dz. cyt., s. 192-202.

${ }^{15}$ Statut Biblioteki Narodowej w Warszawie, Warszawa 1969, § IV, pkt. 5.

${ }^{16} \mathrm{~W} \$ 11$ można przeczytać, m.in.: „Biblioteka prowadzi działalność naukową, instrukcyjnometodyczną, dokumentacyjna, unifikacyjną $\mathrm{i}$ usługową w dziedzinie bibliotekoznawstwa, bibliografii, informacji naukowej, czytelnictwa, edytorstwa i nauk pokrewnych, a także w zakresie konserwacji materialów bibliotecznych". Zob. Statut BN, dokument elektroniczny: http://www.bn.org.pl/o-bn/statut-bn

${ }^{17} \mathrm{Na}$ temat badań czytelnictwa prowadzonych w IKiCz i powstających na ich podstawie opracowań zob. m.in.: S. Siekierski, $Z$ badań nad kulturq literacka, „Przegląd Humanistyczny”, 1994, nr 3, J. Kolodziejska, Lokalność i uniwersalność bibliotek. Warszawa 2000, s. 130-143; recenzja Aliny Kapciak, „Rocznik Biblioteki Narodowej", 39-40:2008, R. Aleksandrowicz, Ksiqzka w życiu i kulturze Polaków - 50 lat serii “Z Badań nad Czytelnictwem”, „Zagadnienia Informacji Naukowej”, 2007, nr 2; W. Sonczyk, Spoteczny zasięg ksiązki i Internetu w roku 2008 - cenny raport z badań, „Studia Medioznawcze”, 2009, $\mathrm{nr} 1$. 
będę się zatem przede wszystkim na dorobku $\mathrm{IKiCz} \mathrm{BN}$, starając się jednak w miarę możliwości nie pomijać innych znaczących dokonań.

Pierwszym rozpoznaniom, jakie na temat czytania ksiązek podjęto w $\mathrm{IKiCz}$, przyświecały głównie cele praktyczne, związane $z$ funkcjonowaniem bibliotek. Analizowano więc m.in. zaopatrzenie tych instytucji $\mathrm{w}$ nowości oraz stopień wykorzystania zakupów jako świadectwo zainteresowań czytelników. Od razu też zainicjowano wydawanie serii „Z Badań nad Czytelnictwem”, w której do chwili obecnej ukazały się w 34 prace. Pierwszą publikacją było Czytelnictwo absolwentów szkót technicznych (1956) autorstwa Marii Walentynowicz, następne to m.in. Zainteresowania czytelnicze w matych miastach na przyktadzie Dobczyc (1959) Janusza Ankudowicza i Kazimiery Ziembickiej, zbiorowe opracowanie Czytelnictwo na tle żcia kulturalnego i struktury spotecznej matych miast (1967), Stanisława Siekierskiego Recepcja literatury pięknej na wsi (1968), Siekierskiego i Ankudowicza Nowości w bibliotekach publicznych (1970), praca zbiorowa Czytelnictwo mtodzieży wiejskiej (1971), Krystyny Kraśniewskiej Czytelnictwo kobiet (1973), Ankudowicza Książka w kulturze uprzemystawianego ośrodka lokalnego (1977), Grażyny Straus Czytelnictwo literatury profesjonalnej (1983) oraz Powszechność i powszedniość lektury (1993), a także trzy kolejne opracowania poświęcone czytelnictwu młodzieży wiejskiej przygotowane przez autorkę niniejszego artykułu: Ksiq̨żka $w$ życiu i kulturze wspótczesnej mtodzieży wiejskiej (1988), Książka wśród mtodzieży wiejskiej (W dziesięć lat później) (1991) oraz Losy wiejskich czytelników ksiazzek. Studium porównawcze (1993). Najnowsze prace wydane w omawianej serii to trzy rozprawy Grażyny Straus, prezentujące wyniki badań prowadzonych $w$ trzech odsłonach na celowo dobranej grupie warszawskiej młodzieży: uczniów pierwszej klasy liceum ogólnokształcącego, uczniów klasy ostatniej - maturalnej i studentów: Czytanie książek u progu liceum (2004), Modelowi sukcesorzy, indywidualiści, eklektycy (2005), Wyksztatceni amatorzy ksiaziek (2008), publikacja Zofii Zasackiej na temat czytelnictwa gimnazjalistów: Nastoletni czytelnicy (2008) oraz praca mojego autorstwa Ksiażka $w$ spotecznej przestrzeni polskiej wsi (2008), poświęcona - jak wskazuje tytuł - mieszkańcom wsi. W serii tej ukazują się także raporty omawiające wyniki ogólnopolskich badań poświęconych społecznemu zasięgowi książki w Polsce, od 1992 r. prowadzonych cyklicznie, co 2 lata. Do chwili obecnej ukazało się 8 opracowań ${ }^{18}$, tom dziewiąty, obejmujący $2008 \mathrm{r}$. znajduje się w przygotowaniu. Część prac z zakresu czytelnictwa prezentowanych jest ponadto w wydawanej od 1972 r. do dziś serii „Materiały Informacyjne Instytutu Książki i Czytelnictwa”. Znaleźć można tu m.in. kolejne opracowania dotyczące zbiorów bibliotek publicznych i ich

\footnotetext{
${ }^{18}$ Zob. G. Straus, K. Wolff, Polacy i ksiąziki. Spoteczna sytuacja ksiq̨zki w Polsce 1992, Warszawa 1996, oraz tychże: Czytanie i kupowanie ksiqzżek w Polsce w 1994 r., Warszawa 1996; Zainteresowanie ksiqzkq w spoteczeństwie polskim w 1996 r., Warszawa 1998; Czytać, nie czytać...Kupować, nie kupować..., Warszawa 2000; Sienkiewicz, Mickiewicz, Biblia, harlequiny..., Warszawa 2002; Czytanie, kupowanie, wypozyczanie, Warszawa 2006, i G. Straus, K. Wolff, S. Wierny, Ksiq̨żka na poczq̨tku wieku. Warszawa 2004 oraz tychże, Czytanie, kupowanie, surfowanie, Warszawa 2008.
}

Z badań nad książką i księgozbiorami historycznymi, 3:2009 
wykorzystania ${ }^{19}$ oraz dwa pierwsze ogólnopolskie raporty na temat czytelnictwa w Polsce w latach 1972 i $1985^{20}$.

Wystarczy przyjrzeć się wymienionym wyżej tytułom prac, by jasny stał się główny zamysi, jaki przyjęto $\mathrm{w}$ IKiCz przy określaniu kierunku badań nad współczesnym czytelnictwem. Po pierwsze, badaniom o zasięgu ogólnopolskim towarzyszą prace środowiskowe, przy czym o wyborze środowiska decyduje jego wpływ na obraz ogólny oraz udzial w obserwowanych zmianach. Stąd więc, np. $z$ jednej strony mamy mieszkańców wsi jako przykład zbiorowości najmniej zainteresowanej czytaniem i hołdującej najbardziej tradycyjnym wartościom, z drugiej zaś - warszawskich licealistów, grupy pod względem czytania wyjątkowo aktywnej oraz predysponowanej (ze względu na swoje cechy spoleczne i kulturowe) do bycia w przyszlości elitą intelektualną. Druga zasada, może mniej widoczna na podstawie samych tytulów prac, polega na utrzymywaniu w miarę możności cykliczności badań, czyli powtarzania co pewien czas wybranych projektów, przy zachowaniu identycznej (lub podobnej) metodologii. Pozwala to patrzeć na zagadnienie w sposób procesualny i lepiej rozumieć aktualną sytuację. Zasada trzecia zaś polega na łączeniu podejścia naukowego $z$ aspektem użytkowym. W naturalny sposób główną grupą zawodową, której potrzeby są uwzględnianie w badaniach $\mathrm{IKiC} z$, stanowią bibliotekarze, zwłaszcza reprezentujący biblioteki publiczne, tj. instytucje dla wielu czytelników służące jako podstawowe źródło książek (a czasami wręcz jedyne). Nic zatem dziwnego, że wśród podejmowanych badań były takie, które wprost koncentrowały się na tych aspektach funkcjonowania bibliotek, które mają wpływ na zachowania czytelników (przykładem rozpoznania dotyczące wykorzystania nowości), a w większości rozpoznań ważne miejsce zajmuje analiza i ocena źródeł dostępu czytelników do książek. Wydawcy i księgarze wynikami prac $z$ zakresu czytelnictwa zaczęli się interesować w zasadzie dopiero po $1989 \mathrm{r}$. W warunkach rynku opartego na zasadach ekonomicznych także w tych środowiskach pojawiło się zapotrzebowanie na wiedzę dotycząca zainteresowań i preferencji czytelników oraz spolecznej struktury publiczności czytającej. Jednocześnie zmiana uwarunkowań określających dostępność publikacji spowodowała, że w badaniach czytelnictwa pojawiła się konieczność uwzględnienia nie tylko zachowań czytelników książek, lecz także ich nabywców. Skutkiem tego od 1992 r. w kolejnych sondażach na temat społecznego zasięgu książki pytaniom dotyczącym czytania zaczął towarzyszyć, podobnie skonstruowany, blok pytań na temat ich kupowania. Mówiąc o tzw. praktykach jako odbiorcach badań czytelnictwa prowadzonych w $\mathrm{IKiCz}$ (w większym lub mniejszym stopniu oddziałujących na

\footnotetext{
${ }^{19}$ Zob. S. Siekierski, W. Adamiec, J. Ankudowicz, Uzupetnianianie i wykorzystanie zbiorów bibliotek publicznych wlatach 1968-1972, Warszawa 1974, W. Adamiec, Gtówne problemy uzupetniania ksiegozbiorów bibliotek publicznych $w$ latach siedemdziesiatych, Warszawa 1989 , oraz kontynuujący ten kierunek badań raport Olgi Dawidowicz-Chymkowskiej, Ksiegozbiory dla dzieci i mtodzieży wiejskich bibliotek publicznych a ich użtkownicy (w druku).

${ }^{20}$ E. Wnuk-Lipińska i E. Wnuk-Lipiński, Problematyka ksztattowania się potrzeb czytelniczych, Warszawa 1975, oraz A. R. Zieliński, Spoteczny zasięg ksiązki w Polsce (raport z badań), Warszawa 1988.
} 
ich kształt) wymienić należałoby jeszcze polityków: urzędników ministerialnych, a w okresie minionym przede wszystkim przedstawicieli aparatu partyjnego, zlecających wykonanie bądź to określonych badań (np. w PRL na temat czytelnictwa tzw. literatury społeczno-politycznej), bądź opracowań, ekspertyz (np. w ostatnim okresie diagnozy o stanie czytelnictwa do Strategii rozwoju kultury oraz materiałów do Raportu o ksiażce na Kongres Kultury Polskiej 2009).

Trzeba też od razu powiedzieć, że nie zawsze i nie wszystkie oczekiwania tzw. praktyków mogły być zaspokojone (pomijając nawet typowo ideologiczne oczekiwania decydentów minionego okresu). Po pierwsze $z$ tego względu, że badania zawsze rejestrują jednak stan ex post, po drugie - ze koncentrują sie one przede wszystkim na zrozumieniu rzeczywistości, a nie przepowiadaniu przyszłości, po trzecie zaś - że na konkretne pytania, w rodzaju, jakie tytuły wydawać lub kupować do bibliotek, mogą odpowiadać tylko w sposób ogólny, np. wskazując na zmienność w czasie wyborów i preferencji poszczególnych grup czytelników różniących się pozycją społeczną i kompetencjamier .

Badaniom czytelnictwa prowadzonym $\mathrm{w} \mathrm{IKiC} z$ od początku towarzyszyła - jak już była mowa - potrzeba refleksji teoretycznej i metodologicznej. Stąd liczne kontakty $z$ innymi instytucjami naukowymi, na początku głównie Pracownią Socjologiczną PAN prof. Józefa Chałasińskiego i Zakładem Czytelnictwa Dzieci i Młodzieży w Katedrze Pedagogiki UW, nieco później - Zakładem Socjologii Kultury na Wydziale Socjologii UW prof. Antoniny Kłoskowskiej, IFiS PAN i IBL PAN, a ostatnio także Instytutem Kultury Polskiej UW.

Szczególnie duży wpływ na prace $z$ zakresu czytelnictwa od samego początku miały więc - jak widać - dwie dyscypliny: socjologia kultury i socjologia literatury. W obu czytanie, zwłaszcza książek, pełni kluczową rolę w rozważaniach poświęconych kulturze symbolicznej oraz społecznym funkcjom literatury, w obu wpisuje się w caly, charakterystyczny dla danej dyscypliny system pojecć, wskaźników, metod i narzędzi badawczych ${ }^{22}$. W przypadku badań $z$ zakresu historii czytelnictwa należałoby jeszcze wymienić dorobek bibliologii i prace poświęcone historii książki, zwłaszcza dotyczące instytucji jej produkcji, dystry-

${ }^{21}$ Zob. K. Wolff, Zasięg książi w Polsce, czyli co czytelnicy $i$ nabywcy książek mają do powiedzenia bibliotekarzom, w: Zbiory i zasoby informacyjne bibliotek publicznych, Warszawa 2009, s. 18-34.

${ }^{22}$ Trudno wymienić wszystkie prace, wskażę więc tylko te, które moim zdaniem miały szczególnie duzy wpływ na badania czytelnictwa, częściowo $z$ tego względu, że zagadnienia te uwzględniały: A. Pawełczyńska, Studia nad czytelnictwem, Warszawa 1969; A. Pawełczyńska, W. Tomaszewska, Urbanizacja kultury w Polsce, Warszawa 1972; A. Kłoskowska, Spoteczne ramy kultury, Warszawa 1972; A. Tyszka, Uczestnictwo w kulturze. O różnorodności stylów życia, Warszawa 1971, i tenże, Interesy $i$ ideaty kultury, Warszawa 1987; B. Sułkowski, Powieść i czytelnicy. Spoteczne uwarunkowanie zjawisk odbioru, Warszawa 1972; J. Lalewicz, Socjologia komunikacji literackiej. Problemy rozpowszechniania i odbioru literatury. Wrocław 1985; tenże, Spoteczny kontekst faktu literackiego i funkcje lektury, „Pamiętnik Literacki”, LXIX, 178, z. 4; S. Żółkiewski, Kultura literacka (1918-1932), Wrocław 1973; J. Kostecki, Uwagi o przedmiocie badań historii czytelnictwa, w: Publiczność literacka, red. S. Żółkiewski, M. Hopfinger, Wrocław 1982, O. St. Czarnik, Między dwoma Sierpniami. Polska kultura literacka w latach 1944-1980, Warszawa 1993; S. Siekierski, Czytania Polaków w XX wieku, Warszawa 2000; tenże, Ksiązka we wspótczesnej kulturze polskiej, Pultusk 2006. 
bucji i rozpowszechniania ${ }^{23}$. Nie można pominąć również dorobku historyków prasy i prasoznawców, obecnie zaś medioznawców, w tym ostatnio przede wszystkim opracowań na temat funkcjonowania Internetu ${ }^{24}$. Stosunkowo mniejszą rolę w kształtowaniu się paradygmatu badań czytelnictwa odegrały natomiast prace pedagogów i polonistó $\mathrm{w}^{25}$, w zwlaszcza metodyków nauczania, koncentrujące się glównie na roli rodziny i szkoły w procesie inicjacji czytelniczej oraz poprawie efektywności nauczania.

Cennym źródłem do badań czytelnictwa są także statystyczne opracowania GUS, przede wszystkim na temat różnych form uczestnictwa w kulturze, w tym również czytania książek, oraz stanu bibliotek, zwłaszcza publicznych. i korzys$\operatorname{tania} z$ nich $^{26}$.

Warto też zauważyć, że od pewnego czasu kwestie związane $z$ książką, jej czytaniem, kupowaniem, posiadaniem domowych księgozbiorów, korzystaniem $z$ bibliotek weszly w obszar zainteresowań dużych, często międzynarodowych sondaży diagnostycznych wykonywanych na zlecenie różnych organizacji, stowarzyszeń, fundacji, administracji państwowy $\mathrm{ch}^{27}$. Widzieć w tym należy przejaw docenienia wskaźnikowej wartości tego rodzaju danych do określania cywilizacyjnych standardów społeczeństw, pomiaru stopnia ich przygotowania do coraz szybszych zmian obejmujących wiele dziedzin życia, oceny umiejętności stałego uczenia się i rozwoju, a nawet rokowań na temat możliwości funkcjonowania demokracji czy społeczeństwa obywatelskiego. Bodajże pierwszym tego rodzaju badaniem, w którym uczestniczyła Polska, był sondaż na temat alfabetyzmu funkcjonalnego przeprowadzony w 1994 r. w 7 krajach pod patronatem

${ }^{23} \mathrm{Z}$ ogromnego dorobku bibliologii warto $\mathrm{w}$ tym miejscu wskazać kilka prac, stanowiących albo próbę ujęcia teoretycznego, albo przykład opracowania źródłowego: K. Glombiowski, Problemy historii czytelnictwa, Wroclaw 1966; K. Migoń, Nauka o książe, Wroclaw 1984; A. Żbikowska-Migoń, Dzieje ksiq̨zki i jej funkcji spotecznej. Wiek XVIII, Wrocław 1987; J. Kostecki, Dzieje czytelnictwa w Polsce (do roku 1945), w: Ludzie i książki, red. J. Kostecki, Warszawa 2006.

${ }^{24}$ Zob. m.in. W. Pisarek, T. Goban-Klas, Aktywność, preferencje i świadomość kulturalna spoteczeństwa polskiego, Kraków 1981; W. Pisarek, Miejsce prasy, radia i telewizji w świadomości kulturalnej Polaków, Kraków 1987; T. Goban-Klas, Media $i$ komunikowanie masowe. Teorie $i$ analizy prasy, radia, telewizji i Internetu, wyd. 2, Warszawa 2004; W. Godzic, Telewizja jako kultura, Kraków 1999; Liternet. Literatura i Internet, red. P. Marecki, Kraków 2002; Spoteczna przestrzeń Internetu, red. D. Batorski, M. Marody, A. Nowak, Warszawa 2006.

${ }^{25}$ Zob. m.in.: $Z$ badań nad czytelnictwem i literatura dla mtodzieży, red. A. Przecławska, Warszawa 1970; Nastolatki $i$ kultura $w$ drugiej połowie lat dziewięćdziesiątych, red. A. Przeclawska, L. Rowicki, Warszawa 2000; S. Bortnowski, Mlodzież a lektury szkolne, Warszawa 1974; tenże, "Potop" w szkole. Odbiór powieści Henryka Sienkiewicza, Warszawa 1988; A. Marzec, Proza wspótczesna w szkole, Warszawa 1980.

${ }^{26}$ Por. W. Łagodziński, Uczestnictwo ludności w kulturze. Podstawowe wyniki badań reprezentacyjnych z lat: 1972, 1979, 1985, 1988 i 1990, Warszawa 1992; Uczestnictwo ludności w kulturze w 2004 r., Warszawa 2006; Spoteczeństwo informacyjne. Wykorzystanie technologii informacyjno-telekomunikacyinych $w 2006 \mathrm{r}$, Warszawa 2007, oraz kolejne roczniki „Kultury” publikowanej przez GUS i „Bibliotek Publicznych w Liczbach" wydawanych przez Bibliotekę Narodową.

${ }^{27}$ Pomijam tu wybitnie usługowe lub okazjonalne sondaze, realizowane na zlecenie czy to określonych instytucji, organizacji, fundacji, czy $z$ własnej inicjatywy ośrodków badania opinii, w których występują pytania dotyczące czytania książek, w różnych kontekstach i sformułowaniach. 
$\mathrm{OECD}^{28}$. Czytanie ze zrozumieniem (reading literacy) jest też stałym punktem międzynarodowego projektu PISA (Programme for International Student Assessment, polska nazwa: Program Międzynarodowej Oceny Umiejętności Uczniów), którego celem jest porównywalność jakości nauczania i organizacji systemów edukacyjnych $w$ krajach biorących $w$ nim udzial ${ }^{29}$. A pytanie wprost o czytanie książek zadawane jest $\mathrm{w}$ sondażu Eurobarometr prowadzonym przez unijny Eurostat w krajach należących (lub, jak to miało miejsce w 2003 r., kandydujących) do tej organizacji ${ }^{30}$. Wśród innych przykładów świadczących o docenieniu roli książki i czytelnictwa wymienić można międzynarodowe badanie poświęcone wiedzy młodzieży na temat zasad funkcjonowania demokracji, w którym za wskaźnik kapitału kulturowego przyjęto posiadanie i liczebność domowych księgozbiorów ${ }^{31}$ oraz rodzimy ranking gmin i powiatów, w którym jednym ze wskaźników aktywności obywatelskiej mieszkańców był odsetek osób korzystających na danym terenie $z$ bibliotek publicznych ${ }^{32}$.

Konkludując, należy więc powiedzieć, że od samego początku badacze czytelnictwa poszukiwali dla uprawianej dziedziny naukowego umocowania, raz eksponując bardziej cele praktyczne, innym razem - poznawcze. Dotychczasowy dorobek badań czytelnictwa umieszcza je wśród nauk społecznych (głównie socjologii kultury i socjologii literatury), przy jednoczesnym wykorzystywaniu wiedzy, która, czy to wprost na temat ksiazzek (w mniejszym zakresie prasy) i związanych $z$ ich obiegiem instytucji, czy zjawisk stanowiących w stosunku do głównego przedmiotu społeczny i kulturowy kontekst, zgromadzona została na terenie innych dyscyplin humanistycznych. W takich okolicznościach zwykło mówić się o interdyscyplinarności, która to cecha - jak widać - jest udziałem także badań czytelnictwa.

\footnotetext{
${ }^{28}$ Polski sondaż objął liczącą 3 tysiące osób ogólnopolską reprezentatywną próbę kobiet i mężczyzn w wieku 16-64 lat. Zob. Literacy, Economy and Society. Results of the First International Adult Survey,Ottawa 2005.

${ }^{29} \mathrm{~W}$ projekcie tym Polska uczestniczy od początku, tj. od 2000 r. Zrealizowane zostały już 3 jego edycje (w roku 2000, 2003 i 2006), kolejna - w roku bieżącym - w przygotowaniu. Por. Raport krajowy $z$ badania PISA 2000. 2003. 2006. Dokumenty elektroniczne: http://www.ifispan.waw.pl/files/gfx/ PISA

${ }^{30}$ W badaniu tym Polska do tej pory reprezentowana była w latach 2001 i 2003 . Należy dodać, że badanie to jest szczególnie cenne, gdyż zastosowana w nim metoda umożliwia porównywanie wyników $\mathrm{z}$ wynikami cyklicznych badań $\mathrm{IKiCz} \mathrm{BN}$ (w obu przypadkach badana jest populacja od 15 lat wzwyż, za pomocą zestandaryzowanego kwestionariusza wywiadu, pytanie odnoszące się do książek obejmuje czytanie w ciaggu roku). Zob. M. Skaliotis, Key Figures on Cultural Participation in the European Union, oraz New Europeans and Culture. Eurobarometer 2003. Dokumenty elektroniczne: http://www.readingeurope.org

${ }^{31}$ Citizenship and Education in Twenty Eight Countries, IEA; K. Koseła, B. Fatyga, Mtodzież $w$ Polsce i w Niemczech na tle sytuacji w obu krajach, Warszawa 1997.

${ }^{32}$ Ranking od 1998 r. prowadzi Centrum Badań Regionalnych i Lokalnych, a jego wyniki publikowane są na lamach prasy; por. pierwsze wyniki: W. Surażska, Liderzy inwestycji samorzqdowych, „Rzeczpospolita", 1999, nr 203.
} 


\section{Podstawowe kwestie definicyjne i towarzyszące im problemy}

Już zaprezentowany wyżej krótki rys historyczny badań czytelnictwa pokazal, że rozpoznaniom na temat czytania (głównie książek i prasy) niemalże od samego początku towarzyszyla świadomość niezbędności refleksji teoretycznej i metodologicznej połączona z przekonaniem o niesamodzielności uprawianej dziedziny. Zrozumiałe jest też, że w zależności od okresu, kierunku, w jakim rozwijały się dyscypliny humanistyczne, w obrębie których badania czytelnictwa sytuowano, definicje podstawowych pojęć oraz stosowane (czy postulowane) metody badawcze różniły się. Dokładne prześledzenie tych kwestii wymagałoby oddzielnego opracowania. Poprzestańmy zatem na tych ustaleniach, które po pierwsze miały - jak się wydaje - największy wpływ na empiryczne prace badawcze z zakresu czytelnictwa i zadecydowały o charakterze konkretnych opracowan, po drugie - trafiły do dydaktyki uniwersyteckiej, tym samym także przyczyniając się do wyznaczenia paradygmatu wiedzy o czytelnictwie.

Jako kluczowe dla dotychczas prowadzonych prac z zakresu czytelnictwa uznać należy cztery pojęcia: książka, czytanie/lektura, czytelnik, czytelnictwo ${ }^{33}$, przy czym w każdym przypadku ważny jest nie tylko teoretyczny aspekt definicji, lecz również jej wymiar operacyjny (o czym mowa będzie w dalszej części niniejszego artykułu).

Zacznijmy od pojęcia ostatniego, jako najszerszego, pozwalającego już na wstępie zorientować się $\mathrm{w}$ zakresie problemów oraz sposobach ich ujmowania i prezentowania ${ }^{34}$. W opublikowanej na początku lat 70. minionego wieku $E n-$ cyklopedii wiedzy o ksiażce mowa jest, że czytelnictwo to: „1. czytanie ksiązek, gazet, czasopism itp. jako zjawisko społeczne, 2. zespół zagadnień związanych ze stosunkiem czytelnika do ksiażki" ${ }^{35}$. Precyzyjniej o przedmiocie badań kierowanego przez siebie Zakładu Propagandy i Organizacji Czytelnictwa (obecna nazwa Pracownia Badań Czytelnictwa) $\mathrm{IKiC} z$ już u progu jego działalności, bo w 1958 r., wypowiadal się Marek Skwarnicki. W referacie Czytelnictwo $i$ metody jego badania, wygłoszonym podczas Krajowej Konferencji Bibliotekarskiej, sformułowal definicję, która - można powiedzieć - na lata wyznaczyła zakres i charakter prac wymienionej placówki: „Czytelnictwo jest procesem polegajacym na zaspokajaniu potrzeb kulturalnych, naukowych i rozrywkowych ludzi poprzez przyswajanie sobie przekazywanego w piśmie dorobku myśli i ducha ludzkiego"36. Podlegała ona następnie różnym modyfikacjom w zależności od zakresu prowadzonych badań oraz aktualizowanych w danym przypadku kon-

${ }^{33}$ Pomijam inne terminy takie, jak „kregi czytelnicze”, ,publiczność czytelnicza”, czy rozróżnienie na czytelnika potencjalnego, rzeczywistego i wirtualnego często występujące w pracach, głównie socjologów literatury i badaczy historii czytelnictwa, choć zwlaszcza dwa pierwsze wydają się dość atrakcyjne wobec zmian, jakie obecnie w procesie komunikowania za pośrednictwem pisma wprowadza Internet

${ }^{34}$ Należy zauważyć, że w bardzo wielu pracach $\mathrm{z}$ zakresu czytelnictwa termin ten wprost nie jest definiowany, a o przyjętym ujęciu świadczy zawartość materiałowa pracy, metodologia i metody badawcze.

${ }^{35}$ Encyklopedia wiedzy o ksiqzice, Wrocław 1971, s. 482.

${ }^{36}$ M. Skwarnicki, Czytelnictwo $i$ metody jego badania, w: Problemy czytelnictwa $w$ wielkich miastach, Warszawa 1960, s. 252. 
tekstów teoretycznych, natomiast jej „duch” pozostal stały. Czytelnictwo traktowano więc jako „formę uczestnictwa kulturalnego”, a zarazem ,jedną z dróg komunikacji społecznej" ze względu na atrybuty książki lub prasy zarówno specyficzną, jak i „lączącą go z innymi formami kontaktu kulturalnego”, na którą skladają się „czynności formułowania oraz odbierania i interpretowania symbolicznych przekazów"37; „zjawisko społeczno-kulturowe, obejmujące szeroko rozumiany odbiór wartości i znaczeń kultury, które jako utrwalone w piśmie teksty językowe są przez ksiązki przekazywane”38. Widziano w nim „formy społecznego krążenia książki i jej odbioru”39, których badanie polega na ustalaniu „rzeczywistej (rzeczywistych) funkcji społecznej (społecznych) książki (różnego rodzaju ksiązek)" ${ }^{40}$, oraz sfere „praktyk komunikacyjnych określonej czasowo i przestrzennie zbiorowości, realizowana za pośrednictwem dwóch korelatów kultury, lub - używając nieco innych pojęć - dwóch rodzajów przedmiotów semiotycznych: książki i czasopisma"41. Należy podkreślić, że wszystkie przytoczone definicje akcentuja spoleczny i kulturowy charakter czytelnictwa jako jednej z form komunikacji. Niektóre wskazują ponadto na nośnik/środek przekazu/ medium, najczęściej książkę, rzadziej - prasę, za pośrednictwem którego proces ten przebiega ${ }^{42}$.

Przywołane definicje wyraźnie zatem wskazują, że czytelnictwa nie należy traktować jako prostej sumy jednostkowych „czytań”, z czym mamy bardzo często do czynienia zwłaszcza w dziennikarskich popularnych i potocznych doniesieniach, koncentrujących się jedynie na danych statystycznych (np. informacji o odsetku czytelników) i niestety często bezkrytycznie przyjmowanych przez przedstawicieli środowisk zawodowych związanych $z$ książką: wydawców, księgarzy, bibliotekarzy. Zauważmy, że o czytelnictwie mówi się jako o procesie, co oznacza branie pod uwagę wielu różnych wskaźników określających stosunek do czytania/lektury, ksiażek/literatury, rozpatrywanie ich w dłuższej

\footnotetext{
${ }^{37}$ A. Kloskowska, Spoteczne ramy kultury, Warszawa 1972, s. 166 i 129.

${ }^{38}$ G. Straus, Czytelnictwo ksiqziek w Polsce w latach dziewięćdziesiątych, w: Nowa encyklopedia powszechna PWN. Suplement, Warszawa 1999, s. 707.

${ }^{39}$ J. Ankudowicz, Problemy i perspektywy czytelnictwa powszechnego, „Rocznik Biblioteki Narodowej”, t. XII-XIII, Warszawa 1979, s. 27.

${ }^{40}$ Tenże, Teoretyczne $i$ metodologiczne problemy badań czytelnictwa, w: Książka w bibliotece $i$ spoteczeństwie, Warszawa 1982, s. 37.

${ }^{41} \mathrm{~J}$. Kostecki, Uwagi o przedmiocie..., s. 177.

${ }^{42}$ Dla porządku należy dodać, że $\mathbf{w}$ literaturze można spotkać się zarówno $\mathrm{z}$ zaprezentowanym ujęciem, skupiającym się na odbiorcy i czytaniu jako formie partycypacji w kulturze, typowym dla badań współczesnych, i ujęciem szerszym $z$ uwzględnieniem nie tylko zjawisk odbioru, lecz także instytucji nadawczych, występującym głównie w pracach historycznych (choć w takich przypadkach mowa bywa raczej o „kulturze czytelniczej” lub „literackiej”). Por. J. Kostecki, Model badań nad historia czytelnictwa, w: Ksiq̨żka i biblioteka w spoteczeństwie. Także Jadwiga Kołodziejska definiuje czytelnictwo jako „naukowe badanie mające za przedmiot książkę jako wartość społecznie funkcjonującą, na którą skladają się: produkcja, drogi rozchodzenia się i recepcji treści, dokonujące się w określonych warunkach społecznych". Zob. J. Kołodziejska, Badania czytelnictwa, w: Encyklopedia wspótczesnego bibliotekarstwa polskiego, red. K. Głombiowski, B. Świderski, H. Więckowska, Wroclaw 1976, s. 18; podobnie Maria Walentynowicz (Podstawy czytelnictwa powszechnego, Wrocław 1970, s. 7-15).
} 
perspektywie czasowej oraz w szerokim kontekście społecznym i kulturowym. Tak też rozumiem intencje Jacka Wojciechowskiego, który stwierdza: „Czytanie występujące $\mathrm{w}$ zbiorowości, więc jako zjawisko spoleczne, albo inaczej: obserwowane $z$ perspektywy zachowań całych grup (a nie - poszczególnych jednostek) jest wlaśnie czytelnictwem. Rzecz jasna procesy lekturowe przebiegają indywidualnie, realizują się w świadomości osób czytających, natomiast czytelnictwo stanowi wypadkową tych procesów oraz ich uwarunkowań"43.

Badanie czytelnictwa zatem - jak każde badanie dotyczące kultury - polega na odnajdywaniu znaczeń zachowań dla danej kultury konstytutywnych i mających określone skutki społeczne. Czytanie ksiazżek (jak również ich kupowanie) traktowane jest jako fakt spoleczny połączony $z$ obowiązującymi w danym miejscu i czasie normami i wzorami kultury oraz rolami społecznymi osób ten rodzaj działań realizujących. Ustalaniu zasięgu w społeczeństwie czytelniczych zachowań towarzyszy więc poznawanie m.in. sytuacji (uwarunkowanych społecznie i kulturowo), w których czytanie jest podejmowane, wyborów i preferencji czytelników, utworów/książek uznawanych przez nich za kanoniczne, wartości przypisywanych lekturze ${ }^{44}$.

W tym miejscu należy więc mocno podkreślić, że sam sondaż (niezależnie od zastosowanego narzędzia) nie jest jeszcze badaniem czytelnictwa, lecz jedynie sposobem zebrania materiałów, które muszą zostać poddane odpowiedniej analizie i interpretacji. Jak powiada bowiem klasyk: „Dane statystyczne same przez się nie czynią socjologii. Socjologią stają się one dopiero po ich socjologicznym zinterpretowaniu, ujęciu w ramach właściwej socjologii struktury znaczeniowej" i dalej: „Zadawanie pytań socjologicznych zakłada chęć dostrzegania czegoś więcej niż powszechnie akceptowane i formalnie określone cele działań ludzkich. Zakłada pewne zrozumienie tego, ze zdarzenia w świecie ludzkim maja różne znaczenia, $z$ których część zakryta jest przed świadomością potoczną"45.

Zatrzymajmy się jeszcze na „czytaniu” definiowanym jako jedna $z$ form partycypacji $w$ kulturze ${ }^{46}$. W wymiarze jednostkowym wiąze się ona $z$ posiadaniem odpowiednich kompetencji, poczynając od technologicznych (jak pokazują m.in. badania nad alfabetyzmem funkcjonalnym nadal bardzo zróżnicowanych), po związane $z$ przygotowaniem do odbioru/konkretyzacji/recepcji różnego typu tekstów, kończąc na odpowiednich nawykach/kodach kulturowych. W ujęciu globalnym, ponadjednostkowym o „czytaniu” mówi się natomiast zazwyczaj jako o historycznie uwarunkowanej praktyce komunikacyjnej odróżniającej kul-

\footnotetext{
${ }^{43}$ J. Wojciechowski, Czytelnictwo, Kraków 2000, s. 18.

${ }^{44}$ Historyczne uwarunkowania lektury oraz rolę instytucji „zapośredniczających” jej przebieg podkreśla m.in. Pierre Bourdieu, Reguty sztuki, Kraków 2001, zwłaszcza w rozdziale Zrozumieć rozumienie, s. 432-475.

${ }^{45}$ P. L. Berger, Zaproszenie do socjologii, przel. J. Stawiński, Warszawa 1995, s. 20,35-36. Na ten temat zob. także np. A. Sulek, Ogród metodologii socjologicznej, Warszawa 2002, s. 13-99.

${ }^{46} \mathrm{~Np}$. wedlug Jacka Wojciechowskiego jest to „szczególna forma zachowania polegająca na twórczym uczestnictwie w pisemnej postaci komunikacji społecznej” (dz. cyt., s. 17).
} 
tury oralne od kultur pisma, a następnie druku $\mathrm{u}^{47}$. Zamiennie $z$ pojęciem czytania, zwłaszcza w opracowaniach materiałowych, funkcjonuje termin „lektura”. Grażyna Straus, w cytowanym już wyżej encyklopedycznym haśle, stwierdza: „Lektura jest działaniem i zarazem sposobem umożliwiajacym poruszanie się wśród wartości i znaczeń zawartych w przekazach książkowych"48. Oba terminy, na ogół traktowane synonimicznie, definiowane były również na gruncie socjologii literatury. Janusz Lalewicz proponowal np. charakterystyczne rozróżnienie: „Czytanie jest pewnym działaniem czytelnika (...) Rozpatrując lekturę jako działanie, można pytać, $z$ jednej strony: Co robi czytelnik $(z$ tekstem), kiedy czyta? - a $z$ drugiej zaś: Co robi czytelnik przez to, że czyta? (...) Innymi słowy, działania czytelnika rozpatrujemy $z$ jednej strony jako pewną technikę czy pewien zespól operacji na tekście, $z$ drugiej zaś - jako środek dokonania czegoś czy też sposób zachowania się w życiu społecznym"19.

Na tym tle czytelnik, to - najogólniej rzecz ujmując - ten, kto czyta, czyli czyni użytek $z$ posiadanej umiejętności, i w ten sposób uczestniczy (mniej lub bardziej świadomie) w zapośredniczonej poprzez pismo formie społecznej komunikacji symbolicznej. Taką właśnie definicję znaleźć można u Jacka Wojciechowskiego: „czytelnik to oczywiście ten, kto czyta, a więc bezpośredni odbiorca tekstu pisanego"50. Jednocześnie zwraca on uwagę, że określenie to „obejmuje zarówno osobę, która w danym momencie czyta tekst, jak też kogoś, kto w ogóle realizuje procesy lekturowe”, stając się „uczestnikiem pewnej formy życia kulturalnego (...), albo ( $z$ komunikacyjnego punktu widzenia) bierze udział w procesie komunikacji, realizowanym za pośrednictwem pisma (druku)"51. Rozróżnienie to dobrze ilustruje koncept stylistyczny, wskazujący, że czytelnikiem „się bywa” - w znaczeniu aktualnie realizowanego aktu lektury, lub „się jest” - w znaczeniu wykazywania w tym kierunku określonych predyspozycji, kompetencji.

Częstym elementem definicji czytelnika jest sam przedmiot lektury, np. w Encyklopedii wiedzy o ksiazzce mówi się, że jest to „bezpośredni odbiorca zawartości książki lub czasopisma"52. Partycypacja w kulturze pisma miała oczywiście różne swoje historyczne odsłony - nie miejsce, by je tu omawiać, literatura na ten temat jest zresztą ogromna - jednak o jej masowości zadecydował dopiero wynalazek druku i ksiazziki w znanej nam powszechnie kodeksowej, drukowanej na papierze, postaci, o której wielu nadal twierdzi, że jest to ,jeden $z$ tych wynalazków (jak młotek, łyżka, nóż, widelec), dla których nie znaleziono w ciagu stuleci lepszych pod względem ergonomicznym odpowiedników"53.

\footnotetext{
${ }^{47}$ Por. m.in.: W. J. Ong, Oralność i piśmienność, przel. J. Japola, Lublin 1992; E. L. Eisenstein, Rewolucja Gutenberga, przel. H. Holender, Warszawa 2004; J. Kostecki, Dzieje czytelnictwa w Polsce (do roku 1945), w: Ludzie i ksiazki, red. J. Kostecki, Warszawa 2006.

${ }^{48}$ G. Straus, dz. cyt., s. 707.

${ }^{49}$ J. Lalewicz, Spoteczny kontekst faktu literackiego i funkcje lektury. „Pamiętnik Literacki”, 69:1978. z. 4 , s. 43.44 .

${ }^{50}$ J. Wojciechowski, dz. cyt., s. 18.

${ }^{51}$ Tamże, s. 19.

${ }^{52}$ Encyklopedia wiedzy o ksiqzice, s. 484.

${ }^{53} \mathrm{U}$. Eco, Nowe środki masowego przekazu a przyszlość ksiazzki, przel. A. Szymanowski, Warszawa 1996, s. 17.
} 
Także badacz Internetu widzi w książe „bardzo przyjazny i poręczny przedmiot" ${ }^{\text {54 }}$. Zauważmy, że również badania czytelnictwa zaczęły rozwijać się dopiero w momencie umasowienia książki.

Sam termin „książka” bywa różnie definiowany, z zależności od dziedziny czy dyscypliny, w obrębie której występuje. Na inne aspekty tego wytworu zwracać będzie uwagę drukarz, na inne wydawca, bibliotekarz, bibliolog, socjolog czy antropolog kultury. Encyklopedia wiedzy o ksiażce podaje sześć sformulowań, w tym: „W potocznym znaczeniu dokument w postaci zespolu kart, zawierających tekst przeznaczony do upowszechniania (zarówno w formie rękopiśmienniczej, jak powielanej różnymi technikami)" ${ }^{55}$. Inne słownikowe definicje to m.in.: „dokument graficzny (znaki pisma, inne symbole, obrazy), gł. w postaci kodeksu, o określonej liczbie stron, zawierający utrwalona myśl ludzka; wydawnictwo zwarte; synonim dzieła piśmienniczego" ${ }^{\circ 6}$ oraz „zlożone i oprawione arkusze papieru, zadrukowane tekstem literackim, naukowym lub użytkowym; też: tekst wydrukowany na tych arkuszach" ${ }^{57}$. Socjolog kultury widzi w książce „środek ponadlokalnego społecznego komunikowania”, „narzędzie pośredniego komunikowania o najdawniejszej tradycji historycznej", antropolog kultury - jeden $z$ „tekstów kultury”, a inspirowany semiotyką socjolog literatury - jeden $z$ wyróżniających się ze względu na aspekt rzeczowy i semantyczny „przedmiotów semiotycznych".

Natomiast w pracach $\mathrm{z}$ zakresu czytelnictwa lekture ksiażek zwykło się traktować jako co prawda jedną $z$ form partycypacji w kulturze druku (obok przede wszystkim czytania prasy), lecz zarazem w jakieś mierze formę szczególną $z$ uwagi zarówno na specyficzne formy ich dostępności i upowszechniania (m. in. w systemie oświaty), jak i sama zawartość, $z$ reguły wymagajaca posiadania odpowiednich kompetencji przy odbiorze. Grażyna Straus stwierdza: „Ze względu na objętość i zlożoność książowych tekstów już samo ich czytanie wskazuje na stosunkowo wysoki stopień piśmienności, a ściślej: biegłość w praktycznym wykorzystaniu tej umiejętności, która oznacza radzenie sobie nie tylko z wszelkimi drukami, ale również z przekazami elektronicznymi, zwłaszcza internetowymi. Dlatego czytelnictwu ksiązek przypisuje się szczególne znaczenie zarówno w skali jednostkowej, jak i spolecznej, o czym świadczą podejmowane przez różne instytucje inicjatywy je propagujące" 558 .

Nawet dość pobieżny przegląd podstawowych pojecć stosowanych w badaniach czytelnictwa utwierdza nas w przekonaniu, że poruszamy się po obszarze

\footnotetext{
${ }^{54}$ M. Castells, Galaktyka Internetu, przel. T. Hornowski, Poznań 2003, s. 224.

${ }^{55}$ Encyklopedia wiedzy o ksiażce, s. 1260.

${ }^{56}$ Nowa encyklopedia powszechna PWN, t. 4, Warszawa 2004, s. 694.

${ }^{57}$ Uniwersalny stownik języka polskiego PWN, t. 2, Warszawa 2003, s. 342.

${ }^{58}$ G. Straus, K. Wolff, S. Wierny, Caytanie, kupowanie..., s. 8. Ma jednak rację Jacek Wojciechowski, gdy upomina się o uwzględnienie periodyków i wszelkiego rodzaju dokumentów (dz. cyt., s. 20-21). Notabene to wlaśnie czytanie ze zrozumieniem tego rodzaju druków sprawiało Polakom najwięcej trudności w badaniu OECD w 1994 r., a liczba przyznających się do nie radzenia sobie $z$ wypelnianiem deklaracji PIT wcale nie maleje.
} 
nauk społecznych oraz, że znaczenie kluczowe przy określaniu przedmiotu badania pelni jedna $z$ historycznie uwarunkowanych form partycypacji w kulturze, a mianowicie ufundowana na wynalazku pisma, następnie zaś i przede wszystkim - druku, i przyjmująca postać kodeksowej, drukowanej na papierze, książki. Jednak inwencja czlowieka w zakresie form/sposobów komunikowania się i wytworów kultury - jak wiadomo - na tym wynalazku nie poprzestała. Pojawiały się kolejne media: fonografia, kinematografia, radiofonia, telewizja, o specyficznym przekazie, odwołującym się do określonych kompetencji odbiorców. Były one odnotowywane przez badaczy czytelnictwa jako oddziałujące na charakter komunikacji społecznej, wzory kultury, style życia itp. W szczególności dotyczy to telewizji. O ile bowiem przez cały XIX i co najmniej pierwszą połowę XX w. (w przypadku polskiej wsi cezurę tę można nawet przesuwać do lat 70. minionego wieku) jedynie lektura (książek i prasy) umożliwiała uczestnictwo w kulturze oficjalnej (w dużej mierze dzięki procesowi edukacji, w którym książka byla glównym narzędziem), o tyle wraz $z$ upowszechnieniem telewizji (przy zasadniczo niezmienionej roli książki w edukacji) proces ten mógł już przebiegać bez jej udziału, a informację i rozrywkę wręcz zdominował przekaz telewizyjny ${ }^{59}$.

Dopiero jednak wynalazek Internetu i jego rosnąca popularność postawil badaczy czytelnictwa w nowej sytuacji. Będąc zarazem środkiem przekazu i przekazem oraz swego rodzaju syntezą dotychczasowych mediów, wchodzi on bowiem także na grunt tradycyjnie związany $z$ funkcjonowaniem książki i prasy, a jednocześnie proponuje zupełnie nowe formy piśmiennicze, zmienia relacje między nadawcą i odbiorcą, uruchamia nowe sytuacje lektury. Jak słusznie zauważa Sebastian Wierny, czytanie w Internecie uchodzić może za praktykę „zarówno najbardziej, jak i najmniej oczywistą. Jest praktyką całkiem oczywista, jeśli wziąć pod uwagę, że cała Sieć $W W W$ jest tekstem, a właściwie hipertekstem, czyli tekstem interaktywnym, pozwalającym, poprzez aktywne odsyłacze (linki), dowolnie i natychmiastowo przemieszczać się pomiędzy milionami rozmaitych, nomen omen, stron internetowych, które składają się na największy na świecie zbiór wszelkiego rodzaju tekstów, ilustrowanych obrazami, muzyka, animacjami, programami itd." ${ }^{\text {. }}$. Badacz czytelnictwa nie może więc abstrahować od tego, co w obszarze piśmienności oferuje Internet, ale też nie może przecież uwzględniać wszystkiego. Internet staje się bowiem i wielkim archiwum lub biblioteka, a właściwie bibliotekami oferującymi piśmienniczy dorobek ludzkości (często $z$ wartością „dodana”, przykładem portal Wolne Lektury), i niespotykanym dotychczas zasobem informacji na temat dostępu do publikacji, wydawnictwem i księgarnią, forum dyskusyjnym skupiającym zwykłych nieprofesjonalnych czytelników, nową formą literackiego salonu, w którym spotykają się autorzy

\footnotetext{
${ }^{59}$ Walter Ong, mając na myśli głównie telewizję, mówil o „wtórnej oralności”, a McLuhan o „globalnej wiosce", badający czytelnictwo zaś wskazywali na syndromatyczność i autonomiczność lektury wobec innych form aktywności, zwłaszcza odbioru telewizji. Zob. W. J. Ong, dz. cyt., zwlaszcza s. 160-185; M. McLuhan, Wybór tekstów, przeł. E. Różalska, J. M. Stokłosa, Poznań 2001, s. 149-207; A. Pawelczyńska, Studia nad..., s. 31-51; A. Kłoskowska, Spoteczne ramy..., zwłaszcza s. 128-139 i 150-180.

${ }^{60}$ G. Straus, K. Wolff, S. Wierny, Czytanie, kupowanie..., s. 141.
} 
i czytelnicy, współczesną agorą - miejscem publicznej, obywatelskiej debaty, narzędziem wykorzystywanym przez władzę i narzędziem, które obywatele moga skierować przeciwko establishmentowi. Obserwujemy formowanie się nowych form wypowiedzi, przykładem grupy dyskusyjne, obecnie określane raczej jako fora internetowe, czaty, blogi, mniej lub bardziej profesjonalne portale, serwisy, niezliczone prywatne strony. Czytanie $\mathbf{i}$ - co ważne - pisanie, jako dwie strony tego samego działania, to immanentna, strukturalna cecha Internetu. $Z$ tego te $\dot{z}$ względu korzystanie $z$ niego bywa traktowane jako aktywny, ale też w pewnym stopniu nowy sposób czytania: „Hipertekst, hipermedia i multimedia interakcyjne są kontynuacją starego już procesu wirtualizacji czytania. Jeśli czytanie jest kwestią selekcji, schematyzacji, tworzenia sieci wewnętrznych odniesień do tekstu (...) integracji słów i wyobrażeń, które wywołują w czyjejś pamięci proces nieustannej rekonstrukcji, to technologie hipertekstowe są czymś w rodzaju obiektywizacji i wirtualizacji procesu czytania"61.

Ponadto badanie rzeczywistości in statu nascendi - niełatwe ze swej natury - w sytuacji, z jaką mamy w tym wypadku do czynienia, jeszcze bardziej się komplikuje. Obserwujemy bowiem, że za rozwojem technologicznym (coraz to nowe możliwości zastosowań Internetu i inne nowe formy dostępu do piśmiennictwa) nie nadąża nie tylko potoczna świadomość (manifestująca się głównie w języku), lecz i refleksja naukowa. Socjologowie, badacze Internetu, medioznawcy, ale również bibliotekoznawcy podejmują próby definiowania wytworów/produktów/dokumentów, które tym nowym technologiom zawdzięczamy. Swoje jednoznaczne i dobrze w społecznej świadomości osadzone znaczenie traci przede wszystkim termin „ksiązka”. Od czasu Internetu zaczynamy mówić o e-książce, książce elektronicznej, przy czym termin ten przechodzi charakterystyczną ewolucję. Raz jest to „elektroniczne urządzenie przenośne, które pozwala wyświetlić zawartość pamięci, np. tekst książki”62, innym razem „odpowiednio przygotowany plik tekstowo-graficzny" ${ }^{63}$, "treść zapisana w formie elektronicznej, przenoszona do odczytania za pomocą odpowiedniego oprogramowania zainstalowanego w urządzeniu komputerowym" ${ }^{\prime 4}$, wreszcie w najbardziej wyczerpującym ujęciu bibliotekoznawcy: „tekst lub hipertekst (który może być wzbogacony o obraz statyczny lub ruchomy oraz dźwięk, wyszukiwarkę czy unikatowy system nawigacyjny) wprowadzany bezpośrednio do pamięci komputera lub przetwarzany na zapis cyfrowy (np. poprzez skanowanie), zapisany w odpowiednim formacie pliku, dystrybuowany za pomocą dysków optycznych lub sieci, odtwarzany na ekranie monitora tradycyjnego komputera PC lub specjalistycznego urządzenia, a także nawiązujący w różnym stopniu do tradycyjnego pojęcia książki”.65.

${ }^{61}$ D. De Kerckhove, Inteligencja otwarta. Narodziny spoteczeństwa sieciowego, przeł. A. Hildebrandt,

R. Glegoła, Warszawa 2001, s. 100.

${ }_{62}$ Stownik informatyczny, Warszawa 2005, s. 151.

${ }^{63} \mathrm{Ł}$. Gołębiewski, Śmierć książki. No future book, Warszawa 2008, s. 57.

${ }^{64}$ Wikipedia.

${ }^{65}$ M. Góralska, Ksiqzika elektroniczna - przeszlość i perspektywy, w: Oblicza kultury książki. Prace 
Sytuacja ta prowadzi do zmian, których w pełni nie jesteśmy jeszcze świadomi, i których nie możemy oczywiście przewidzieć, choć - jak to zwykle bywa w takich momentach - nie brakuje wizjonerów, przepowiadaczy przyszłości, entuzjastów zmian i usposobionych do nich pesymistycznie, w czym jak zwykle przodują publicyści, wśród których pewna część wyraźnie preferuje złe wiadomości i lubuje się w slowie „kryzys”. Nam bliskie jest raczej podejście Manuela Castellsa, gdy mówi: „Moją rolą nie jest być optymistą lub pesymistą, nie staram się też sformułować jakiejś populistycznej ideologii. Ja tylko obserwuję i badam zjawiska. Moim zadaniem nie jest również przewidywanie przyszłości - moje analizy służą wylącznie zrozumieniu teraźniejszości”66. Jednak opowiedzenie się po stronie obiektywnej neutralności bynajmniej nie ułatwia zadania. Sprawy nie rozwiązuje odwołanie się do najbardziej ogólnej definicji czytelnictwa jako procesu polegającego na „zaspokajaniu potrzeb kulturalnych, naukowych i rozrywkowych ludzi poprzez przyswajanie sobie przekazywanego w piśmie dorobku myśli i ducha ludzkiego"67, gdyż w obecnej sytuacji staje się ona wyjątkowo nieprecyzyjna. Czy jednak problem lączy się tylko $z$ określeniem przedmiotowego zakresu badań, czy może - przede wszystkim z powodu interaktywności i hipertekstowości cechujących Internet - ma szerszy charakter i wymaga głębszej rewizji sposobów ich uprawiania? Na obecnym etapie trudno - jak się wydaje wątpliwość tę rozstrzygnąć. Nie ulega natomiast kwestii, że niezależnie od swego zakresu przedmiotowego „czytelnictwo” pozostaje „zjawiskiem społeczno-kulturowym, obejmującym szeroko rozumiany odbiór wartości i znaczeń kultury"6r, co nie zmienia też usytuowania prowadzonych na ten temat badań wśród nauk społecznych.

\section{3. „Kuchnia” badacza czytelnictwa}

Teoretyczne ustalenia w momencie, gdy dochodzi do gromadzenia danych, muszą znaleźć swoje empiryczne odpowiedniki, a więc przeksztakcić się $\mathrm{w}-$ można powiedzieć - definicje operacyjne. W praktyce oznacza to dobór odpowiednich materiałów źródłowych, właściwych wskaźników oraz narzędzi badawczych. Poprawność metodologiczna jest podstawowym i niezbędnym warunkiem wiarygodności każdej pracy naukowej. W przypadku nauk społecznych w grę wchodzi uwzględnienie podmiotu badania, tj. jednostki społecznej. Dyrektywa ta, sformułowana przez Floriana Znanieckiego, znana pod nazwą „współczynnika humanistycznego”, oznacza konieczność uwzględniania postaw, przekonań, poglądów, wiedzy badanych osób odnośnie do przedmiotu, który interesuje naukowca. „Gdy badam grupę społeczną, język, teorię naukowa, muszę je brać tak,

\footnotetext{
i studia z bibliologii i informacji naukowej, red. M. Komza, Wroclaw 2005, s. 21. Jednak nawet korzystajac z tej definicji, moglibyśmy mieć wątpliwości, jak potraktować osoby, które np. pod adresem www.archiwumagnieszkiosieckiej.pl czytają poezję i pamiętniki Agnieszki Osieckiej, nie mówiąc już o uczestnikach projektu „Kumpel z Przeszłości - 1944 LIVE”, którzy na Facebooku, z reguły wchodząc $w$ interakcje, śledzili losy dwojga bohaterów podczas Powstania Warszawskiego.

${ }^{66}$ M. Castells, Sieć nasza powszednia, „Gazeta Wyborcza”, 2009, nr 137.

${ }^{67}$ M. Skwarnicki, dz. cyt., s. 252.

${ }^{68}$ G. Straus, Czytelnictwo ksiazzek..., s. 707.
} 
jak je doświadczają i czynnie realizują podmioty ludzkie” - pisał on w Socjologii wychowania, jednocześnie dystansując się od zarzutu psychologizowania - „nie znaczy to jednak, że badam stany świadome i procesy psychiczne tych ludzi, lecz właśnie grupę, język, teorię" ${ }^{99}$. Drugi obowiązek łączy się $z$ koniecznością krytycznej analizy wykorzystywanych źródeł i narzędzi, a więc rozważenia zarówno ich zalet, jak i wad. Badania czytelnictwa jako odnoszące się do kultury i społeczeństwa obu tym zasadom jak najbardziej podlegaja. Ich stosowanie jest jedyną gwarancją uniknięcia artefaktów, o które tak łatwo zwłaszcza w sytuacji, gdy zainteresowanie naukowca skupia się na kwestiach dla badanych niemających znaczenia pierwszorzędnego, i gdy staje on przed koniecznością - by tak rzec - zorganizowania sobie materiałów. Mniej problemów nastręczaja zbiorowości, które niejako ze swej natury i obowiązu wytwarzają świadectwa lektury. Janusz Kostecki, biorąc pod uwagę role, jakie ich przedstawiciele pełnią w komunikacji społecznej, wyróżnia dwie takie grupy: „znawców, czyli kreatorów i strażników wartości (wśród nich badaczy i krytyków literackich)" oraz „mediatorów, czyli tych, którzy odpowiadają za upowszechnienie (wśród nich m.in. cenzorów, nauczycieli, „przewodników-wychowawców”)"70. Pozostaje jednak grupa najliczniejsza - cytowany autor mówi o niej jako o „czytelnikach potocznych" - w odniesieniu do której takich utrwalonych świadectw lektury w zasadzie nie posiadamy. Należy je zatem wytworzyć, wywołać, w praktyce zaś zapytać o sprawy często - jak już była mowa - mało dla badanych ważne (wyjątkiem niektóre dokumenty autobiograficzne odnotowujące interesujące nas kwestie, często jednak powstające na konkretne zamówienie i także $z$ tego względu nie w pełni wiarygodne) ${ }^{71}$. Oczywiste jest też, że każdorazowo przy organizacji badania pierwszorzędne znaczenie ma jego cel, wpływający na dobór badanej zbiorowości (inaczej mówiąc: próby), wybór metod i narzędzi badawczych oraz kontekstów interpretacyjnych ${ }^{72}$. Do gromadzenia materiałów najczęściej wykorzystywane są badania empiryczne, mające wszelkie cechy sondaży opinii, prowadzone $\mathrm{z}$ zastosowaniem takich narzędzi jak standaryzowany kwestionariusz (głównie wywiadu, rzadziej ankiety ${ }^{73}$ ) lub - gdy w grę wchodzi pogłębione

${ }^{69}$ F. Znaniecki, Socjologia wychowania, t. 2, Warszawa 1973, s. 18.

${ }^{70} \mathrm{~J}$. Kostecki, Czytelnik w świecie wartości, w: Dokument, ksigzka i biblioteka w badaniach naukowych i nauczaniu uniwersyteckim, red. M. Skalska-Zlat, A. Żbikowska-Migoń, Wroclaw 2008, s. 94.

${ }^{71} \mathrm{Nie}$ będę tu mówiła $o$ źródłach, $z$ których korzystają badacze historii czytelnictwa. Ich analizę na gruncie polskim przeprowadzil m.in. Janusz Kostecki w artykule Dzieje czytelnictwa w Polsce (do roku 1945), w: Ludzie i ksiqzki, s. 12-17.

${ }^{72} \mathrm{Na}$ temat metodologii badań społecznych zob. m.in. S. Nowak, Studia z metodologii nauk spotecznych, Warszawa 1965; tenże, Metodologia badań spotecznych, Warszawa 1970; K. Kosela, A. Sułek, Metody badania procesów spotecznych, Warszawa 1983; A. Sułek, Ogród metodologii...

${ }^{73}$ Te drugie sprawdzają się przede wszystkim podczas badania zbiorowości skupionych w tym samym czasie w jednym miejscu, a więc np. uczniów, i mają wówczas charakter ankiety audytoryjnej, lub podczas badania opinii, poglądów. Ankietę audytoryjną wykorzystały m.in. Grażyna Straus i Zofia Zasacka. Zob. G. Straus, Czytanie ksiazzek u progu liceum, Warszawa 2002, i Modelowi sukcesorzy, indywidualiści, eklektycy, Warszawa 2005; Z. Zasacka, Nastoletni czytelnicy, Warszawa 2008; ankietę dodaną do jednego z zeszytów publikacji seryjnej zastosował Eugeniusz Kloc w artykule Wspótczesna polska powieść kryminalna w oczach jej odbiorców (na przyktadzie serii „Ewa wzywa 07...”), „Rocznik Biblioteki Narodowej”, 17/18:1981-1982. 
badanie jakościowe - dyspozycje do wywiadu swobodnego ${ }^{74}$. Jako kluczowa pojawia się więc $w$ tej sytuacji kwestia, o co pytać i jak formułować pytania. Podczas wywiadu, czy wypełniając ankietę, respondent prowokowany jest bowiem do wypowiadania się na tematy interesujące badacza, dla niego zaś zazwyczaj niezbyt istotne, często nieuświadamiane, bywa że nawet nigdy wcześniej niewerbalizowane.

Kolejna trudność łączy się $z$ koniecznością zaproponowania odpowiednich miar zjawiska oraz ich typologią i interpretacją, czyli właściwym odczytaniem wskaźnikowej zawartości odpowiedzi i dobraniem najbliższego intencjom badanych klucza znaczeniowego. Natura przedmiotu badania jest bowiem taka, ze wiele odpowiedzi ma charakter ogólnikowy i stereotypowy, co wprawdzie utrudnia ich interpretację, lecz zarazem w pełni oddaje charakter zjawiska, jakim jest czytelnictwo nieprofesjonalistów, a więc osób $\mathrm{z}$ reguły nieuzbrojonych w odpowiedni - typowy dla znawców - aparat, pozwalający mówić o książce, lekturze, literaturze ${ }^{75}$.

Dylematy tego rodzaju od dawna towarzyszyły badaczom czytelnictwa i różnie próbowano je rozstrzygać. Bez odwołania się do konkretnych przykładów trudno kwestie te omawiać. Posłużę się jednym rodzajem badania - w powszechnym odczuciu uważanym za podstawowe, i takim, na którym skupia się uwaga zarówno naukowców, jak i praktyków: wydawców, księgarzy, bibliotekarzy. Jego celem jest odpowiedź na pozornie proste pytania, jaka część społeczeństwa czyta książki i jakie? Sondaż na ten temat prowadzony jest w IKiC $z$ BN, od lat 90. minionego wieku - jak już była mowa - cyklicznie, co 2 lata i ze względu na swój charakter funkcjonuje pod nazwą „badania zasięgowego"76. Pierwszym warunkiem uzyskania wiarygodnych danych jest zwrócenie się $z$ pytaniami do właściwej zbiorowości, czyli próby, gdyż rzadko badaniem można objąć wszystkich. W przypadku omawianego sondażu jest nią reprezentacja calego społeczeństwa ${ }^{77}$, której odpowiednia pod względem statystycznym konstrukcja pozwala uzyskane wyniki, w zakresie dozwolonym dla danego badania, uogólnić na całą populację ${ }^{78}$.

Kolejna kwestia dotyczy terminów „czytać”, „czytać książki”, definicje których przytaczane były wcześniej. Przystępując do realizacji sondażu, należy jednak

${ }^{74}$ Zob. G. Straus, Wyksztatceni amatorzy ksiazek, Warszawa 2008; R. Chymkowski, Sposoby i funkcje czytania literatury pięknej przez mbodzież studiująca $w$ Warszawie, praca doktorska napisana pod kierunkiem prof. dr. hab. Stanisława Siekierskiego w Instytucie Kultury Polskiej UW (maszynopis).

${ }^{75}$ Por. J. Kostecki, Czytetnik w świecie wartości, dz. cyt.; G. Straus, Nieprofesjonalne kryteria wartościowania lektur, „Rocznik Towarzystwa Literackiego im. A. Mickiewicza”, 26/27:1991; L. Bartczak, Elementarz gustów czytelniczych: kryteria oceny ksiq̨żek z literatury pięknej przez czytelników nieprofesjonalnych, w: $Z$ badan nad wspótczesnym funkcjonowaniem ksiażki, Warszawa 1991.

${ }^{76}$ Por. przypis 18.

${ }^{77} \mathrm{Z}$ przykładem reprezentatywnego badania mieszkańców wsi mamy do czynienia w pracy K. Wolff, Ksiqżka w społecznej przestrzeni mieszkańców wsi, Warszawa 2008, a gimnazjalistów w pracy Z. Zasackiej, Nastoletni czytelnicy, dz. cyt.

${ }^{78} \mathrm{Na}$ temat niedoskonałości próby reprezentatywnej zob. m.in. Mit próby reprezentatywnej. Dokument elektroniczny: http://www.pentor.pl/17534.xml?MEDIA 
odpowiedzieć sobie na kilka bardziej szczegółowych pytań. A zatem, czy chodzi nam o książki przeczytane w całości (przynajmniej z grubsza), czy może także o czytanie wybranych fragmentów (typowe przy korzystaniu $z$ publikacji takich, jak encyklopedie, słowniki, poradniki, ale także podręczniki, czy książki fachowe), a może nawet tylko o ich przeglądanie. $W$ prezentowanym badaniu przyjęto wszystkie wymienione formy kontaktu $z$ książkami traktować jednakowo. Jest oczywiste bowiem, że niektóre pozycje czyta się „od deski do deski”, inne tylko wybiórczo, a jeszcze inne głównie ogląda. Jeśli natomiast chodzi o samą książkę, to we wszystkich dotychczasowych badaniach typu „zasięgowego" uznawano ją za przedmiot oczywisty, niewymagający definiowania i pozostawiony uznaniu samych respondentów, w myśli strawestowanej i w tym wypadku dobrze się sprawdzającej zasady: „koń jaki jest, każdy widzi”79.

Taki szeroki zakres badania (biorący pod uwage wszystkie typy książek i wszystkie sytuacje lektury) ma jeszcze inne konsekwencje. Tam, gdzie sięganie do ksiazzek bywa zachowaniem $\mathrm{z}$ różnych względów, zarówno nawyku, jak i obowiązku, faktycznie powszednim i codziennym, część kontaktów, zwłaszcza $z$ książką użytkową (przykladem sytuacja ucznia korzystającego $z$ podręcznika, czy osoby sprawdzającej hasla w encyklopedii, slowniku itp.) nie zawsze jest uwzględniana. $Z$ kolei tam, gdzie książka bywa rzadkościa, także tego rodzaju sytuacje są na ogól skrupulatnie odnotowywane.

Analizując odpowiedzi na temat czytania książek, nie można również abstrahować od wartości, jaką przedstawia ten rodzaj zachowania i ogólnie ten wytwór kultury. Obowiązuje nas wszak dyrektywa „współczynnika humanistycznego". Tam gdzie czytanie książek sytuuje się odpowiednio wysoko wśród wartości uznawanych, można spodziewać się wyższej deklaratywności, aniżeli tam, gdzie zachowanie to ma charakter raczej przypadkowy, sytuacyjny, bywa tylko jedną $z$ wielu aktywności, mało specyficzną ${ }^{80}$. Dziedzictwo przeszłości wynikające $z$ faktu, że przez wieki książka stanowiła jeden $z$ głównych atrybutów ludzi wyksztakconych, kulturalnych, inteligencji, mimo obecnych zmian spowodowanych procesami zachodzącymi w kulturze takimi, jak zanikanie hierarchii i kanonów, indywidualizacja, wreszcie - komercjalizacja, nadal w jakiejś mierze obowiazuje. Mówiąc wprost, do nieczytania i nieznajomości literatury w niektórych środowiskach przyznawać się nie wypada bardziej niż w innych. Po przeanalizowaniu powyższych uwarunkowań należy stwierdzić, że pytanie o czytanie książek ujawnia zarówno „bywanie” czytelnikiem, jak i „bycie” nim, i w efekcie prowadzi do wyznaczenia maksymalnego zasięgu książki w społeczeństwie (nawet w pewnym stopniu potencjalnego). Na tym tle chyba oczywiste jest, że in-

\footnotetext{
${ }^{79}$ Podobnie jak w czasach Benedykta Chmielowskiego koń stanowił nieodlączne i oczywiste wyposażenie każdego szlachcica, tak drukowana na papierze książka po blisko pięciu wiekach swej obecności, w tym ponad wieku na skalę masową, stała się przedmiotem powszechnie znanym. Por. G. Straus, Powszechność i powszedniość lektury, Warszawa 1993, s. 188-203. Sluszność takiego podejścia potwierdziły również odpowiedzi czytelników na temat wyborów książek. Zupełnie incydentalnie pojawiał się tu, np. tytuł czasopisma.

${ }^{80}$ Zob. M. Stefanowska, Odbiorcy kultury - deklaracje i rzeczywistość, Warszawa 1988, s. 102-126.
} 
formacje na temat intensywności czytania należy traktować jedynie szacunkowo, oddzielając czytających niewiele, od wykazujących większą pod tym względem aktywność. W przywoływanych tu badaniach „zasięgowych” przyjęto wyróżniać czytelników sporadycznych, deklarujących kontakt w ciągu roku nie więcej niż z 6 książkami (Straus mówi o nich jako o „odbiorcach” książek, widząc w nich raczej „spoleczne zaplecze czytelnictwa”" ${ }^{\text {) }}$ oraz czytelników właściwych mających na swoim rocznym koncie co najmniej 7 tytułów.

Mówiąc o intensywności, dochodzimy do innego istotnego problemu, który wiąże się $z$ badaniami czytelnictwa, a mianowicie konieczności stosowania wobec obserwowanych zjawisk określonych miar. Ich różnorodność, tak jak i arbitralność, wydaje się sprawą oczywistą, każdorazowo powinna bowiem łączyć się $z$ celem badania oraz jego środowiskowym i problemowym zakresem. Przykładowo trudno takie same skale stosować $z$ jednej strony do uczniów, studentów czy tzw. znawców, z drugiej zaś - osób instytucjonalnie i kulturowo do czytania niezobligowanych. W poświęconych czytelnictwu sondażach badanie tej kwestii przyjmuje postać różnych pytań: od dotyczących czytania książek w ogóle, przez czytanie przebiegające w określonym czasie (np. ostatnim miesiącu, pólroczu, roku), do ustalania jego częstotliwości i ilości przeznaczanego na ten cel czasu (często $z$ rozróżnieniem na dzień powszedni i świąteczny). Praktyczny skutek tego jest jednak taki, że wielość sondaży nie przekłada się na dającą się zsumować informację ${ }^{82}$.

W przywolywanych tu jako przykład sondażach „zasięgowych” za najlepszą miare, jaką można posłużyć się w odniesieniu do ogółu mieszkańców, uznano $\operatorname{rok}^{83}$. Wynika to $z$ faktu, że czytanie na ogół nie przebiega rytmicznie, często ma charakter sytuacyjny, lączy się $z$ okresami nauki, pracy, wypoczynku, a zatem rok daje większą gwarancję uwzględnienia rozmaitych okoliczności, charakterystycznych dla różnych środowisk i jednostek (choć w przypadku osób czytających dużo może powstać problem uwzględnienia wszystkich lektur).

Wprawdzie już same deklaracje na temat czytania - o czym starałam się przekonywać - mają określony walor poznawczy, to istnieją dość proste sposoby, by próbować je uwiarygodnić. Pierwszym jest pytanie o wybór czytanych książek: ich tytuły, nazwiska autorów, ewentualnie typy, rodzaje. W przypadku

${ }^{81}$ G. Straus, K. Wolff, Sienkiewicz, Mickiewicz..., s. 17.

${ }^{82}$ Zob. R. Mendruń. Nieuchwytny mianownik - czytelnictwo ksiq̨żek a rynek, (maszynopis). Już w latach 50. ubiegłego wieku Bernard Berelson rozważal przyjęcie różnych kryteriów: przy czytaniu przynajmniej 2 książek rocznie czytelnikami byloby ok. 50\% obywateli Stanów Zjednoczonych, przy co najmniej 1 książce tygodniowo zaledwie ok. 7\%, a przy co najmniej 1 ksiażce miesięcznie - na co ostatecznie się zdecydowal - 25-30\%. Zob. B. Berelson, Who Reads What Books and Why, w: Mass Culture, red. B. Rosenberg. D. M. White, Chicago 1957, cyt. za A. Kloskowska. Spoleczne ramy..., s. 156.

${ }^{83}$ Kryterium przynajmniej 1 książki na 2 miesiące, tj. co najmniej 6 rocznie zastosowano w pierwszych badaniach $\mathrm{IKiCz}$, zob.: J. Ankudowicz, K. Ziembicka, Zainteresowania czytelnicze w malych miastach na przyktadzie Dobczyc, Warszawa 1959; J. Ankudowicz, Czytelnictwo na tle życia kulturalnego i struktury spotecznej matych miast, Warszawa 1967; K. Ziembicka-Ankudowicz, Biblioteki $i$ czytelnicy w wybranych matych miastach, Warszawa 1968, oraz w badaniach bełchatowskich Antoniny Kłoskowskiej, zob. A. Kloskowska, Spoleczne ramy kultury, Warszawa 1972. 
prezentowanego sondażu przybiera ono postać pytania otwartego, co pozwala wyeliminować zarzut narzucania czytelnikom kategorii badacza i ogranicza deklaratywność ${ }^{84}$. Osoby, które wcześniej zadeklarowały czytanie, zwłaszcza intensywne, a nie są w stanie nic więcej na ten temat powiedzieć, prezentują się mako wiarygodnie. Otwarta forma pytania posiada jeszcze jeden dodatkowy walor, pozwala mianowicie uchwycić sposób, w jaki czytelnicy zwykli mówić o książkach. Interesujące wydaje się ustalenie, czy posługują się oni takimi kategoriami, jak tytul i autor (charakterystycznymi dla znawców i profesjonalnych norm lektury), czy mówią raczej ogólnie o typie, rodzaju książek (np. romans, sensacja, fantastyka), ich przeznaczeniu (potrzebne do pracy, szkoły), adresacie (książki dla dzieci, młodzieżowe).

Wróćmy jednak do pytania o wybory jako głównego sposobu pozyskiwania informacji na temat zainteresowań czytelników. W przypadku sondażu „zasięgowego" obejmuje ono - przypomnijmy - cały rok poprzedzający badanie. Należy wziąć pod uwage, że zwłaszcza osoby czytające dużo często nie są w stanie zrelacjonować wszystkich swoich lektur, a ci, którzy umieszczają lekturę wysoko wśród uznawanych wartości są bardziej skłonni do składania deklaracji niekoniecznie pokrywających się ze stanem faktycznym. Zdarza się więc, ze jedni (zwłaszcza czytelnicy mało wyrobieni, o niezbyt bogatym dorobku) jako ostatnie lektury wymieniają jedyne znane im, głównie ze szkoły, tytuły. Inni starają się „uwodzić” badacza swoją erudycją, i mówią nie tylko o tym, co faktycznie czytali, lecz także o tytułach znanych, głośnych, cenionych, nagrodzonych, itp., prezentując typową dla inteligencji postawę „oświeconego dyletanta”85. Dla badacza kultury, który widzi w niej system zinternalizowanych wartości nie stanowi to problemu, przeciwnie - dobrze określa istotę zagadnienia. Ci jednak, którzy tego rodzaju dane chcieliby wykorzystać w swojej działalności zawodowej, a więc np. wydawcy czy bibliotekarze muszą brać pod uwagę, $z$ jakiego rodzaju faktami mają do czynienia ${ }^{86}$.

\footnotetext{
${ }^{84} \mathrm{~W}$ wielu sondażach pytanie o wybory ma postać pytania zamkniętego, co wynika glównie $\mathrm{z}$ wygody badacza, otrzymującego szybko gotowy materiał. Wieloletnie doświadczenia badań czytelnictwa pokazuja jednakże, że podejście takie może prowadzić do nieporozumień, a w efekcie nawet zafalszowań. I tak, np. dla jednego czytelnika pod określeniem „ksiązka historyczna” kryje się Trylogia Sienkiewicza. inny ma na myśli twórczość Pawła Jasienicy lub Normana Davisa, a jeszcze inny nawet powieści Tadeusza Dołęgi-Mostowicza czy Heleny Mniszek. Podobnie bywa z określeniami takimi, jak „książa wojenna” (dla jednych to typowa literatura sensacyjna, dla innych literatura faktu, praca naukowa lub popularnonaukowa), „książka psychologiczna” (obejmująca szerokie spektrum od romansu, obyczajowej powieści, przez poradnik, do rozprawy naukowej) czy „książka religijna” (można tu znaleźć modlitewnik i Biblię, książki Jan Pawła II i jemu poświęcone, albumy prezentujące sztukę sakralną, krajobrazy Ziemi Świętej, zdjęcia z podróży papieskich, poezję księdza Jana Twardowskiego i żywoty świętych).

${ }^{85}$ Por. J. Kurczewska, Inteligencja, w: Encyklopedia socjologii, t. 1, Warszawa 1998, s. 337-343; G. Straus, Modelowi sukcesorzy..., s. 12-22.

${ }^{86} \mathrm{O}$ tym, że dane zgromadzone w tego rodzaju badaniu zawieraja wiele informacji praktycznych, przydatnych m.in. w pracy bibliotekarskiej starałam się przekonywać wielokrotnie, zob. np. K. Wolff, $O$ ksiazkach $i$ czytelnikach, czyli jak czytamy $i$ co z tego wynika, w: Spoteczne oddziatywanie wspótczesnej ksiqzżi, Warszawa 2002; tejże, Zasięg ksiażki $w$ Polsce, czyli co czytelnicy i nabywcy ksiażek majq do powiedzenia bibliotekarzom, w: Zbiory i zasoby informacyjne....
} 
Swobodne wypowiedzi czytelników dotyczące wyborów można oczywiście różnie porządkować w zależności przede wszystkim od badanego środowiska i celu badania. W przywoływanym sondażu „zasięgowym” przyjęło się rozróżnianie literatury pięknej i niebeletrystycznej, książek autorów polskich i obcych, uwzględnianie najpopularniejszych typów publikacji oraz najczęściej wymienianych tytułów i autorów. Dwa pierwsze rodzaje klasyfikacji raczej nie budzą wątpliwości, choć przecie $\dot{z}$ nawet podział na literaturą piękną i niebeletrystyczną nie zawsze bywa oczywisty, zwlaszcza w przypadku niektórych utworów współczesnych, których autorzy świadomie zacierają granice gatunkowe (por. dokument fabularyzowany, współczesna sylwa) ${ }^{87}$. Natomiast podział publikacji na typy ma charakter autorski i lączy się $z$ charakterem tego konkretnego badania, tj. - przypomnijmy - realizowanego na ogólnopolskiej reprezentatywnej próbie mieszkańców od 15 lat wzwyż, a więc w zbiorowości zróżnicowanej pod względem płci, wieku, wykształcenia, zatrudnienia, miejsca zamieszkania oraz kompetencji czytelniczych i sytuacji uprawiania lektury. Przy jej konstruowaniu kierowano się przede wszystkim wypowiedziami samych czytelników. Istotne było, by kategoryzacja objęla typy występujące najczęściej, ukazując w miarę możności całe spektrum wyborów czytelników, a zarazem takie, które są istotne $z$ ich perspektywy (tj. zauważalne, wyróżniane, a nawet wprost w ten sposób nazywane). W efekcie zaproponowano następujący podział piśmiennictwa, w którym kryteriom rodzajowym towarzyszyły sytuacyjno-funkcjonale: lektury szkolne i podręczniki, książki encyklopedyczno-poradnikowe, książki dla dzieci i młodzieży, ksiązki fachowe, książki religijne, literaturę obyczajowo-romansową, sensacyjno-kryminalną, fantastykę, literaturę faktu, eseistykę i publicystykę oraz ezoterykę i ufologię. Wyraźne dążenie do sfunkcjonalizowania typologii nie wyeliminowało calkowicie arbitralności, ponadto pewna grupa wyborów nie znalazła miejsca $w$ żadnym $z$ typów. Dotyczy to zarówno ksiązek beletrystycznych, jak i niebeletrystycznych, na ogół utworów wybieranych przez nielicznych, często "trudniejszych", przez znawców określanych jako wysokoartystyczne lub klasyczne. Tak skonstruowana typologia stara się więc unikać bezpośredniego wartościowania i przypomina nieco, sformulowaną na gruncie socjologii literatury, koncepcję obiegów. Poszczególnym typom często towarzyszą bowiem, podobnie jak w przypadku obiegów, określone instytucje i mechanizmy nadawczo-dystrybucyjne, odpowiednie formy promocji i reklamy oraz zakladany adresat $^{88}$.

${ }^{87}$ Zob. P. Czapliński, P. Śliwiński, Literatura polska 1976-1998. Przewodnik po prozie i poezji, Kraków 1999, s. 239-283.

${ }^{88}$ Por. Żółkiewski, Kultura literacka... Inne podejście zaproponowała Antonina Kłoskowska w badaniach belchatowskich. Polegało ono na przyporządkowaniu wyborów czytelników do 4 poziomów: elementarnego, obejmującego lekturę szkoły podstawowej łącznie $z$ podręcznikami, literaturę dewocjonalną i literaturę dla dzieci i młodzieży; popularnego, na który składały się romans, sensacja, powieść przygodowa, poradniki; klasycznego, zawierającego klasykę polską i obcą odpowiadającą kanonom szkoły średniej, literaturę faktu, ksiażki popularnonaukowe, literaturę zawodową; i wyższego (określanego także jako elitarny), na który składała się literatura awangardowa, glównie współczesna, klasyka odleglych epok i dalekich pod względem etnicznym kultur, literatura nasycona refleksją filozoficzną lub naukową, 
W badaniach czytelnictwa czytelnik charakteryzowany jest nie tylko poprzez wskaźniki określające intensywność lektury i wybory, często pod uwagę brane sa także jego preferencje/upodobania (pytania dotyczące lubianych typów książek, ulubionych autorów itp.), opinie na temat tekstów według badanych kanonicznych (pytania o książki polecane i towarzyszące temu uzasadnienia). Ważną rolę pełni wiedza o sposobach, w jakich zaopatruje się on w książki oraz o źródłach informacji, z jakich korzysta, dokonując wyboru. W myśl tego, o czym mowa byla w części poświęconej definicjom, dopiero suma ich wyników będzie stanowila o obrazie czytelnictwa traktowanego jako forma partycypacji w kulturze. Trzeba jednak powiedzieć także, że dorobek współczesnych badań czytelnictwa zdominowany jest przez prace o charakterze ilościowym. W rezultacie jakościowe ze swej natury zjawiska kultury wyodrębnia się i opisuje za pomocą wskaźników ilościowych, co przypomina „przechodzenie ilości w jakość”. Znaczenia nabierają bowiem te zjawiska, fakty, oceny, opinie, których jest stosunkowo dużo, przede wszystkim to, co ma charakter typowy. Jednostkowe upodobania, zainteresowania, pojedyncze dzieła, oryginalne, samoistne zjawiska, czyli wszystko to, co wymyka się typom i nie poddaje się standaryzacji, przy takim ujęciu można powiedzieć - nie istnieje. W konsekwencji nasz czytelnik staje się czytelnikiem statystycznym, jego indywidualne jednostkowe doświadczenia zostają zastapione abstrakcyjną konstrukcją. Opracowanie materiałów ilościowych polega więc zazwyczaj na szacunkowej ocenie zjawisk i zmusza w wielu wypadkach (przykładem prezentowane kategoryzacje czytelników czy typologia lektur) do arbitralnych decyzji.

Do tych, pokrótce zaprezentowanych, dawnych dylematów badań czytelnictwa, doszły nowe, które w „kuchni” badacza czytelnictwa pojawiły się glównie za sprawą Internetu. Jeśli bowiem nawet zgodzimy się odnośnie do podstawowych terminów, to ich operacjonalizacja, a więc przelożenie na pytania, które pozwoliłyby - jak już mowa była wcześniej - „zorganizować” material badawczy, rodzi wiele, zupełnie nowych problemów. Internet bowiem nie tylko częściowo odwzorowuje formy tradycyjne, oferując tzw. e-ksiażki rozumiane jako rodzaj substytutu równolegle funkcjonujących książek tradycyjnych, czyli drukowanych na papierze, a następnie poddanych zabiegowi digitalizacji, oraz umożliwia dostęp do publikacji wyłącznie elektronicznych (born-digital), które jednak poprzez fakt posiadania autora, tytułu, a głównie wydawcy wyodrębniająca się w sieci trochę na podobieństwo swojej starszej siostry. Ale proponuje też wlasne formy piśmiennicze (Wikipedia, blogi), a wreszcie przynosi calą masę tekstów do czytania, którym trudno przypisać jakąs stałą nazwę. Z punktu widzenia czytelnika są to po prostu teksty o czymś, informacje na jakiś temat, do których dociera on glównie poprzez popularne wyszukiwarki, przy czym wybór tematyki może być zarówno świadomy, wynikający $z$ zainteresowań i potrzeb internauty, jak

dramaty, poezja wspólczesna i dawna mniej popularna, zwłaszcza obca, eseje, monografie literackie, artystyczne, literatura naukowa, filozoficzna. Jednak ich ustalenie w jakiś względnie obiektywny sposób (np. na podstawie nagród) czy jednolitej oceny znawców okazalo się, jak przyznała autorka, bardzo trudne. Zob. A. Kloskowska, Spoleczna ramy... 
i zupełnie przypadkowy, będący efektem internetowej „nawigacij" ${ }^{89}$. Internetowe czytanie może być zatem i $w$ gruncie rzeczy jest prawie identyczne $z$ czytaniem tekstów przekazywanych tradycyjnie, w postaci drukowanej na papierze książki, np. wówczas gdy źródłem są zasoby cyfrowych bibliotek, archiwów (o ile problemem nie jest sama forma czytania $z$ ekranu), lub do niego zbliżone, gdy poprzez system linków nawiązuje do jednoczesnego korzystania z kilku ksiazzek. Ale może też znacznie się różnić, np. gdy mamy do czynienia ze strukturą hipertekstową, zawierającą wiele możliwości/dróg odbioru, burzącą tradycyjnie sztywny podział na nadawcę i odbiorcę, lub tekstami niezamkniętymi, rozwijającymi się w czasie (np. blogami). Widzimy więc, że Internet bardzo komplikuje sytuację badania czytelnictwa i zmusza do stawiania pytań podstawowych: o przedmiot badania i zakres, dobór wskaźników, możliwość stosowania odpowiednich miar obserwowanych zjawisk, zachowań (np. w przypadku gdy korzystanie $z$ odsylaczy buduje całą sieć „czytań” - dla użytkownika Internetu zwykle niespecyficznych, jeśli nawet jakoś porównywalnych $z$ jednoczesnym korzystaniem $z$ kilku książek). Na swego rodzaju próbę wystawiona zostaje jednak przede wszystkim dyrektywa naczelna „współczynnika humanistycznego", chroniąca badacza przed tworzeniem artefaktów na skutek rozmijania się jego założeń i definicji z postawami i opiniami badanych. Jak bowiem pytać o czytanie w sieci, jak je selekcjonować i porządkować, w sytuacji, gdy te ostatnie są nie tylko niejednoznaczne, lecz często nieznane, gdy szybko się zmieniają i różnicują, gdy nie działa społeczny uzus w odniesieniu nawet do podstawowej terminologii? Pod tym względem jesteśmy ciągle na początku drogi i, podobnie jak w wielu innych dziedzinach, nie nadążamy za wyjątkowo szybko przebiegającymi zmianami technologicznymi. Wiedza, jaką na temat użytkowania Internetu dostarczają nawet stosunkowo liczne sondaże prowadzone przez różne ośrodki badawcze, może być w tym przypadku pomocna tylko w ograniczonym i zupełnie podstawowym zakresie $^{90}$. Trzeba jednak stwierdzić, że w cyklicznych badaniach $\mathrm{IKiCz}$ poświęconych czytelnictwu fakt „wtórnej piśmienności” Internetu dostrzeżony został bardzo wcześnie. Analiza przeprowadzona w 2002 r. pokazała, że „piśmienność komputerowa rozwija się na identycznym podłożu społecznym, jak piśmienność tradycyjna" ${ }^{\prime \prime 1}$. W związku $z$ tym w sondażu następnym, w 2006 r., kwestia czytania w sieci poddana została staranniejszemu oglądowi. Pytano o czytanie podstawowych, a zarazem wyróżniających się (także - jak można sądzić - w odczuciu społecznym) form przekazów tekstowych: wiadomości, informacji na portalach, ogólnie witryn, stron, prasy, blogów, forów dyskusyjnych oraz książek/ e-książek ${ }^{92}$. Wyniki tego sondażu, nie zaprzeczając wprawdzie wcześniejszej te-

${ }^{89}$ Jak ważne $\mathrm{z}$ punktu widzenia internauty są tekstowe zasoby Internetu pokazują m.in. wyniki badania Priorytety rozwoju spoteczeństwa informacyjnego w opinii internautów. Dokument elektroniczny: http://www.mswia.gov.pl/portal/SZS/548/7024

${ }^{90}$ Por. inicjatywy badawcze w rodzaju Diagnoza społeczna, Polskie Badania Internetu czy publikacje GUS, np. Spoteczénstwo informacyjne...

${ }_{91}^{1}$ G. Straus, K. Wolff, S. Wierny, Ksiażka na poczatku.... s. 44.

${ }^{92}$ G. Straus, K. Wolff, S. Wierny, Czytanie, kupowanie... 
zie o powiązaniu piśmienności komputerowej $z$ tradycyjną, wskazały na zmniejszanie się udziału czytelników książek wśród użytkowników Internetu (dodajmy, że bylo to polączone w ogóle ze spadkiem deklarujących czytanie ksiązek ${ }^{93}$ ). Mogłoby więc powstać podejrzenie, że część czytelników „przenosi się” do Internetu. Posiadany material nie pozwala hipotezy tej jednoznacznie zweryfikować. $\mathrm{Z}$ jednej strony bowiem wśród deklarujących czytanie nie zmienia się odsetek tych, którzy jako źródlo czytanych książek podają Internet, $z$ drugiej zaś - wśród internautów ponad trzykrotnie rośnie odsetek deklarujących czytanie w sieci ksiażek/literatury/lektur/większych plików tekstowych. Za obserwowane różnice odpowiedzialna może być więc - jak się wydaje - także metodologia badania. Rozwiazaniem - jednak tylko $z$ pozoru najprostszym i tylko technicznym - może być wyraźne rozdzielenie w badaniu czytania książek papierowych i elektronicznych. Przypomnijmy, że w dotychczasowych sondażach czytanie ksiazżek traktowane było szeroko, a więc pod uwagę brane były wszystkie typy publikacji, także typowo funkcjonalne: encyklopedie, słowniki, poradniki, oraz różne zakresy i sposoby korzystania $z$ nich, w tym czytanie fragmentów, wybranych informacji itp. Większość tego rodzaju form i funkcji lektury w Internecie okazuje się po prostu nie do „wyśledzenia”, co wynika z samej natury tego medium. Nie może być zatem mowy o takiej kompatybilności zachowań, która uprawomocniałaby np. ich sumowanie. Dylematy, dotyczące m.in. stabilności tekstu, oddziaływania środka przekazu na odbiór, funkcjonowania kręgów opiniotwórczych, można by jeszcze mnożyć. Wiele jednak wskazuje, że wraz $z$ pojawieniem się Internetu piśmienność nie oznacza już tego samego, co w epoce druku, a zatem i badania czytelnictwa stają przed zupelnie nowymi i niekonwencjonalnymi wyzwaniami. Niektóre pojęcia (takie jak książka, czytanie) trzeba definiować ponownie, by dopiero na tej podstawie wyznaczyć zakres problematyki badawczej. Rozważenia wymagają też stosowane dotychczas metody i narzędzia badawcze, łącznie $z$ wykorzystaniem Internetu jako źródła i narzędzia.

Nie podlega dyskusji, że sprawcą największego zamieszania na polu badań czytelnictwa stal się obecnie Internet. Nie można jednak pomijać także innych zjawisk, których dostarcza rynek i współczesna kultura - coraz bardziej skomercjalizowana i wyraźnie konsumpcyjna. Zauważmy, że książa pojawia się w pakiecie innych mediów oraz dóbr (tzw. gadżetów) i coraz bardziej jako taka traci swą specyfikę: staje się częścią gazety, filmu, nagrania muzycznego, gry komputerowej, czy wreszcie całego ogromnego projektu często określanego mianem „produktu totalnego" ${ }^{94}$ lub „globalnego produktu medialnego" ${ }^{95}$. Na rynku

\footnotetext{
${ }^{93} \mathrm{~K}$. Wolff, Spoteczny zasięg ksiązi w Polsce $w 2008$ roku - komunikat z badań Biblioteki Narodowej. Dokument elektroniczny: http://www.bn.org.pl/download/document

${ }^{94}$ M. Zając, Promocja ksiązki dziecięcej, Warszawa 2000, s. 163-174.

${ }^{95}$ Por. A. Has-Tokarz, W.I.T.C.H. (mania) jako przyktad globalnego produktu medialnego dla dzieci, w: Bestsellery. Literatura popularna. Odbiorcy. Empiryczne badania wspótczesnego czytelnictwa, Lublin 2009 , s. $29-46$.
} 
mamy też produkt określany jako „książka multimedialna”96, co do którego trudno powiedzieć, czy liczy się w nim bardziej tekst, obraz, dźwięk, animacja, gra, i audiobooki, dostępne w coraz większym wyborze i cieszące się rosnącą popularnością. Wymienione wytwory $\mathrm{w}$ jakiejś mierze nawiązują do tradycyjnej książki, nawet w nazwach, czy jednak ich użytkownicy są skłonni widzieć je i o nich mówić tak, jak badacze (bibliotekoznawcy, medioznawcy)?

Wiele więc wskazuje, że czas pewnej stabilizacji budowanej przez cały miniony wiek zarówno w czytelnictwie (od zachowań wyraźnie nacechowanych kulturowo i społecznie, po zachowania w coraz większym stopniu powszednie i niespecyficzne), jak i jego badaniach (poszukujących swojego paradygmatu $\mathrm{z}$ wykorzystaniem dorobku różnych dyscyplin naukowych $\mathrm{i}$ w konfrontacji z praktyka) skończył się. Ostatni taki moment zarejestrowała Grażyna Straus, analizując wyniki badań „zasięgowych” w latach 1992-2004: „Ostatnia dekada ubieglego wieku i pierwsze lata XXI stulecia okazaly się raczej czasem stabilizowania granic społecznego obiegu książi i krystalizowania się zbiorowości jej polskich odbiorców. Na przełomie wieków nie doszło więc do przełomu w czytelnictwie"97. Minęły jednak zaledwie dwa lata i odsetek deklarujących czytanie książek zmniejszyl się o 8 punktów procentowych, by w ciągu dwu następnych spaść o kolejne 12 punktów ${ }^{98}$. Czy zatem sytuacja dojrzała już do tego, by zacząć zastanawiać się nad nowym paradygmatem badań czytelnictwa - w chwili obecnej nie potrafię powiedzieć. Sądzę jednak, że kwestia ta powinna stać się - i to w najbliższej przyszlości - przedmiotem głębszej refleksji, do której chciałabym tym tekstem zachęcić.

${ }^{96}$ B. Taraszkiewicz, Ksiqzika multimedialna na CD-ROM w Polsce, Warszawa 2003; M. Góralska, Ksiqzżka elektroniczna..., A. Dróżdż, Ksiq̨żka w świecie utopii, Kraków 2006. s. 219-230.

${ }_{97}$ G. Straus, Czytelnictwo ksiązek na przetomie tysiqcleci, w: Ludzie i ksiqżki, s. 51.

${ }^{98}$ K. Wolff, Spoteczny zasięg ksiq̨żi w Polsce w 2008 r. - komunikat z badań Biblioteki Narodowej, dz. cyt. 